\title{
The Single Gothic Towers of the Two Franciscan Churches of Bratislava and Sopron and Their Possible Connections to Vienna
}

\author{
Zoltán BERECZKI
}

\begin{abstract}
The medieval Franciscan monasteries of Bratislava (Slovakia) and Sopron (Hungary) are important representants of the Gothic architecture of the former Hungarian Kingdom. An extensive research executed between 2013 and 2017 has proven that the construction of their towers was closely related to the workshop of the Stephanskirche, Vienna; and that they are important milestones in the evolution of the Gothic spires, with significantly earlier construction date as it is widely accepted in the literature. This article is based on the corresponding parts of the author's $\mathrm{PhD}$ thesis defended in 2017 . $^{1}$
\end{abstract}

Keywords: Gothic architecture, monasteries, Bratislava, Sopron, Vienna

\section{Introduction}

The golden age of Gothic church towers (with Robert Bork's expression 'great spires') ${ }^{2}$ was the 14th-15th centuries. The first openwork spire was constructed in Freiburg im Breisgau (completed around 1330), ${ }^{3}$ and it soon became a general paragon, an archetype. ${ }^{4}$ (Fig. 20., left) Until the completion of the north spire of the Straßburg cathedral in 1439 the title of the tallest stone tower in Europe was owned by the Viennese lodge with the south tower of St. Stephen's church (Stephanskirche). (Fig. 20., right) This was completed in 1433, and its 137-meter height was only a few meters shorter than the new record holder of Straßburg (142 m). It is important

1 BERECZKI, Z.: Gótikus tornyok épitésének kérdéséhez: Mit mondanak a megvalósult épületek a tervezésról, mit mondanak a tervek. a megvalósulásról? Ph.D. thesis. University of Pécs 2017.

2 BORK, R.: Great spires. Skyscrapers of the New Jerusalem. Köln 2003, p. 9, footnote 4.

3 Ibidem, p. 156. to note that the Straßburg tower was erected on the top of an already existing structure, while the Viennese workshop started its construction from the foundations.

About a century passed between the completion of the Freiburg and the Vienna towers. The Viennese tower had significantly improved upon the Freiburg one not only artistically, but structurally as well. This improvement did not happen in one single step. Two smaller Gothic towers in the one-time Kingdom of Hungary, cca. 70 kilometers from Vienna and each other, represent two important stages of this evolution: the one of the Franciscan monastery in Bratislava, and the one of the Franciscan (now Benedictine) monastery in Sopron. ${ }^{5}$ The significance

${ }^{4}$ About the great spires in detail, see BORK 2003 (see in note 2).

5 The manuscript of a conference presentation by Michael Viktor Schwarz was crucial for the research. The author is grateful to him for sharing it. SCHWARZ, M. V.: Gotische Türme diesseits und jenseits der Reichsgrenæe: Wien, Deutsch-Altenburg, Sopron, Bratislava. Manuscript, 2013. 
of the two towers is raised by the fact that surprisingly few carved Gothic stone spires were preserved on the territory of the Kingdom of Hungary: the towers of St. Michael's church in Sopron, the former Franciscan church in Sopron, (Fig. 1.) and the Franciscan church in Pressburg (now Bratislava, Slovakia). ${ }^{6}$ (Fig. 2.)

\section{The tower of the Franciscan church in Pressburg (Bratislava)}

The Franciscan monastery of Pressburg is situated in the immediate vicinity of the main square, on a square named after the Franciscans (Františkánske námestie, Franziskanerplatz, Ferenciek tere). The entire building complex is of outstanding importance for the history of architecture. ${ }^{7}$ The choir of the church, St. John's chapel, parts of the clerestory, and, to some extent, the tower date back to the Middle Ages. (Fig. 3.)

\section{The current state of the tower}

The tower was completely restored in the last decade of the 19th century under the supervision of Frigyes Schulek: it was first partly disassembled and then rebuilt. ${ }^{8}$ A garden pavilion was built in the Aupark (today Janko Král' Park) using the old stones.

${ }^{6}$ Before 1919 the German name of the city (Pressburg) was commonly used in the English language. That's the reason for using it in this paper discussing earlier events, instead of the modern name, Bratislava.

7 Its architectural history is discussed in POMFYOVÁ, B.: Stredoveká architektúra žobravých reholí na Slovensku - stav výskumu a problémové okruhy. In: Architektúra klástorov a reholných domov na Slovensku : dejiny a pamiatková ochrana. Eds.: KVASNICOVÁ, M. - ŠEREGI, M. Bratislava 2018; POMFYOVÁ, B.: Letnery v stredovekých kostoloch na Slovensku : príspevok k stavebným dejinám mendikantských kláštorov. In: Archaeologia historica, 44, 2019, no. 2, pp. 715-747; BUDAY, P.: K stavebným dejinám františkánskeho kostola $\mathrm{v}$ Bratislave. In: Bratislava. Zborník Múrea mesta Bratislavy, 24, 2012, pp. 2951.; and CIULISOVÁ, I.: Stredoveká podoba bratislavského františkánského kostola. In: Ars, 33, 2000, no. 1-3, pp. 78-93.

8 For details, see BUDAY 2012 (see in note 7), BERECZKI, Z.: The reconstruction of the Bratislava Franciscan Monastery's tower in the 19th century. Pyramid or dome? In: Ars, 48, 2015, no. 1, pp. 95-105. This wasn't unusual at that time: the

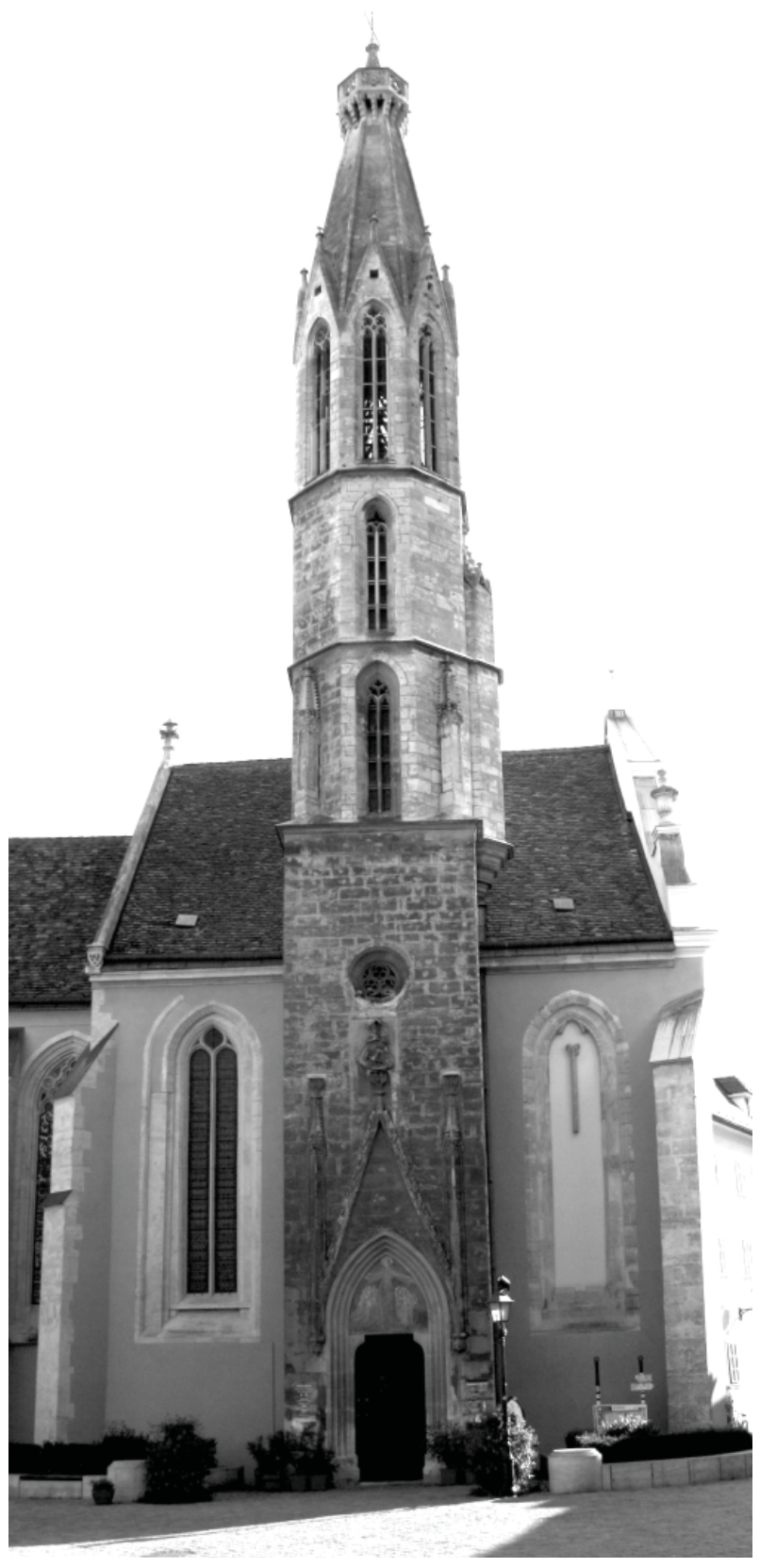

Fig. 1: The former Franciscan church of Sopron from the north. Photo: Zoltán Bereçłoi

spires of both the Stephanskirche and the Maria am Gestade in Vienna were entirely reconstructed in the 19th century. NIERHAUS, A.: Vollendung unerwünscht. In: Der Dombau von St. Stephan. Die Originalpläne aus dem Mittelalter. Wien 2011, p. 111-113., HASSMANN, E.: Meister Michael: Baumeister der Herzoge von Österreich. Wien 2002, p. 257-263. 


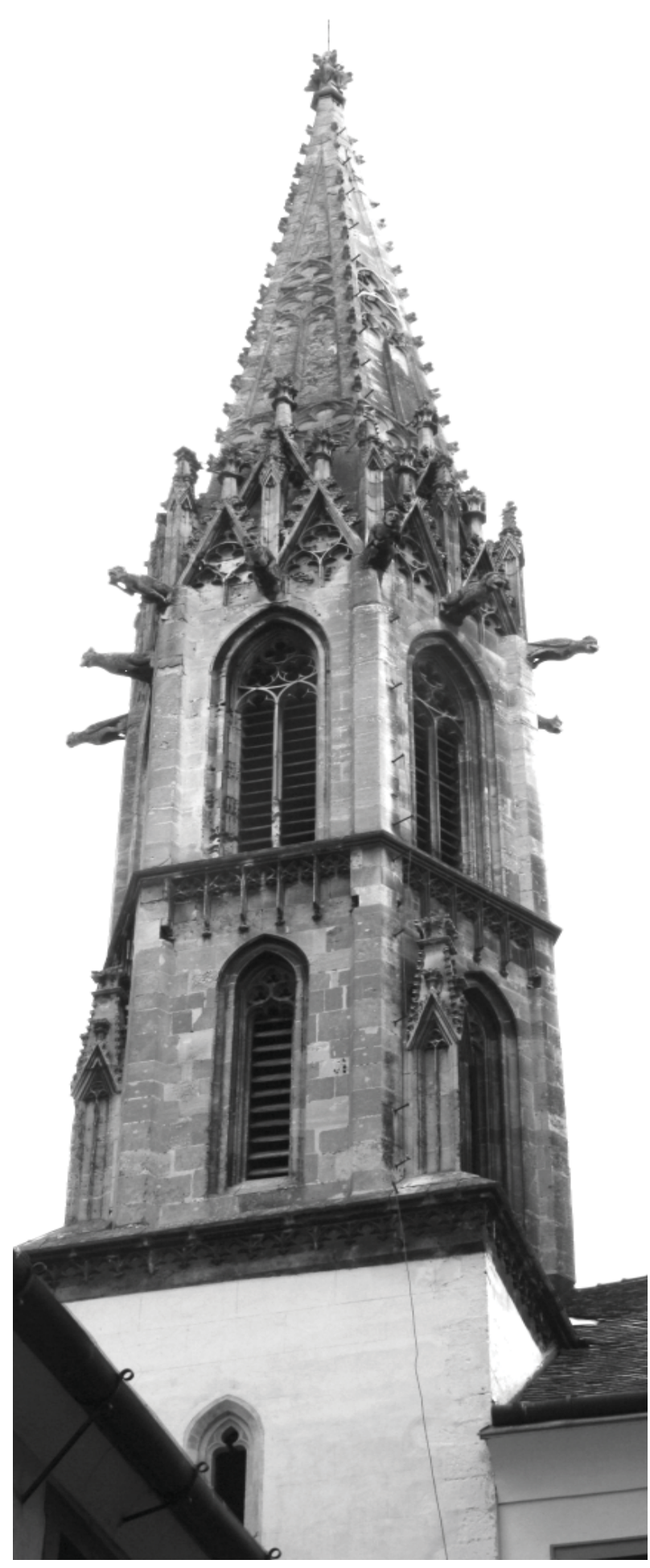

Fig. 2: The tower of the Franciscan church in Bratislava / Pressburg. Photo: Zoltán Bereczkei
But there is an important difference between the tower of the monastery and the pavilion: while the aforementioned has a pointed, pyramid-like spire, the latter's termination is curved and dome-shaped. 20th century Hungarian and (Czech)slovak literature considered this latter, dome-like termination as an original, medieval form, which Schulek had judged as "irregular" and then had "straightened". This belief led to a series of misconceptions about the tower's medieval construction history. However, examination of the files, drawings, photos, and plans of Schulek's reconstruction prove that the original spire was pyramid-shaped as well, and during the reconstruction an almost exact copy of the original was rebuilt. ${ }^{9}$

The only real conceptual difference between the dismantled and the reconstructed tower can be observed on the spire. All the archive photos and authors who had seen the original tower support the statement that earlier the tower had had an openwork spire. ${ }^{10}$ This fact has great significance for the history of arts: this is the only known openwork Gothic spire on the territory of the Kingdom of Hungary. The openwork was bricked up before the 19 th century, but it is unknown exactly when. On the reconstruction plans and on the reconstructed tower the spire is a closed stone pyramid. ${ }^{11}$ In the archive files of the reconstruction there are no hints about why they chose the closed spire instead of the openwork. Probably structural reasons can explain the decision.

A thorough on-site inspection of the pavilion, which was built using the stones of the dismantled tower, indicate that the building is not an exact copy

9 About the reconstruction, the question of the pyramid or dome, the differences between the old and the new tower and the garden pavilion, see BERECZKI 2015 (see in note 8).

${ }^{10}$ RÓMER, F.: Pozsony régészeti műemlékei. In: Pozsony és környéke: Egy földtani térképpel és több ábrával. 1865, p. 287, HENSZLMANN, I.: Magyarország csúcs-ives stylü müemlékei. Györ, Soprony, Pozsony, S₹-György, Bazin, Modor és Nagy-Szombat. Budapest 1880, p. 105.

${ }^{11}$ Gyula Forster National Centre for Cultural Heritage Management, Archive for Plans, Folder of the Pressburg Franciscan Monastery, drawing no. K 7252. 


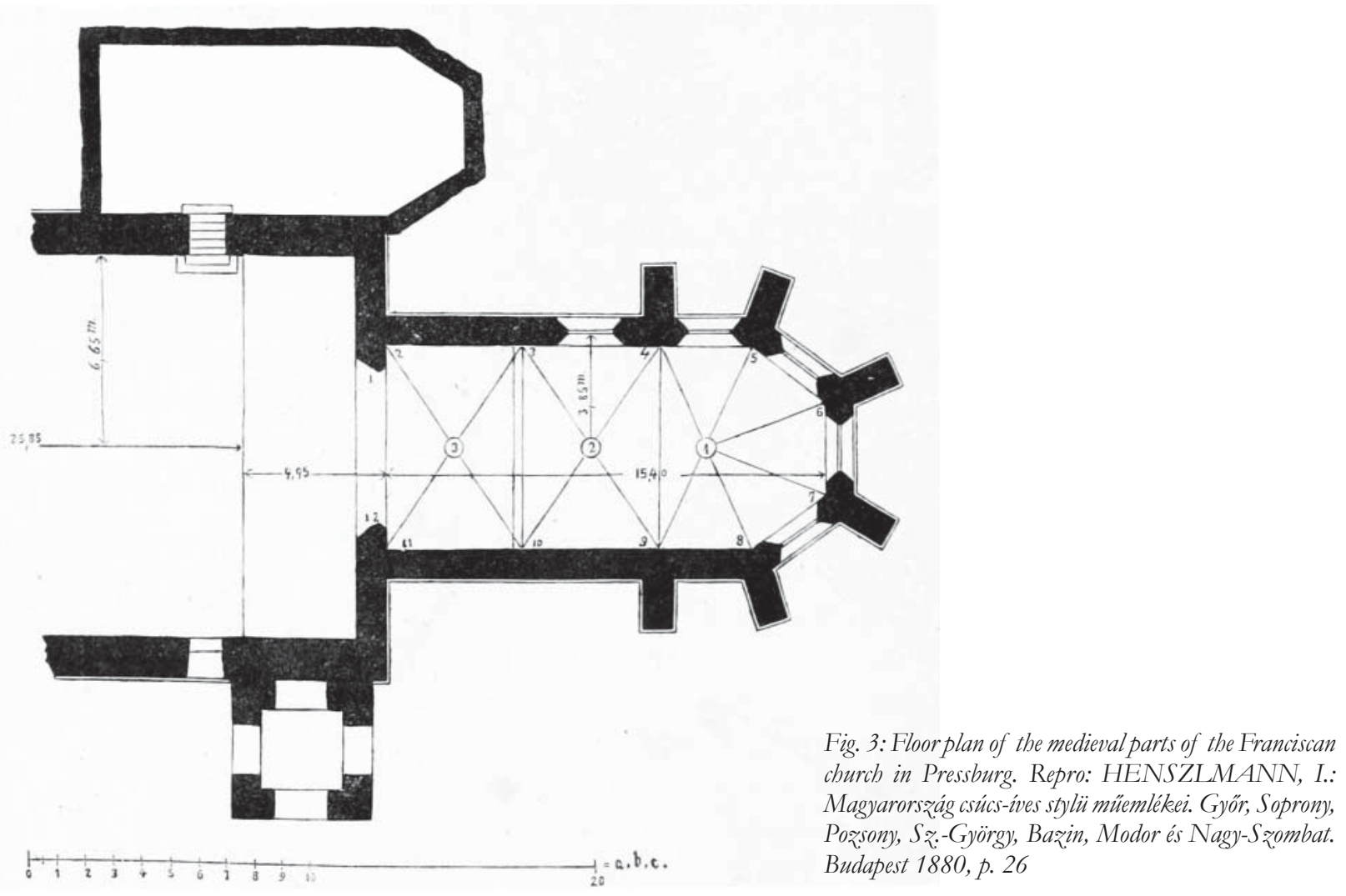

Fig. 3: Floorplan of the medievalparts of the Franciscan church in Pressburg. Repro: HENSZLMANN, I.: Magyarország csúcs-ives stylü müemlékei. Györ, Soprony, Pozsony, Sz:-György, Bazin, Modor és Nagy-Szombat. Budapest 1880, p. 26

of the original structure. However, the two buildings (the garden pavilion and the reconstructed tower), together with the archive photos and drawings, are still suitable for drawing conclusions. Most of all, according to the available data, the most interesting part of the structure - the area of the gables - is an exact copy of the original on the new tower, ${ }^{12}$ and this part of the garden pavilion is also put together with the least amount of additional material.

The historic representations of the original tower - considering the inevitable simplifications in the drawings - display a relatively unified look, ${ }^{13}$ so

12 BERECZKI 2015 (see in note 8), p. 102.

${ }^{13}$ MENCL, V. - MENCLOVÁ, D.: Bratislava- stavební obraz. mèsta a hradu. Praha 1936; TÖRÖK, E.: Mikoviny Sámuel, 1698-1750 (Virtuális kiállítás). Online: http://mek.oszk. hu/06400/06422/html/index.htm [3. 8. 2016]; CIULISOVÁ, I.: Gotická svätyňa františkánskeho kostola Pany Márie v Bratislave. In: Umèní, XLVI, 1998, pp. 174-187, p. 175. the structure has certainly been largely unchanged since its first depiction.

More important reports were published about the tower in the 1860s. In 1862 the Wiener Baubütte published a detailed and relatively accurate survey documentation. ${ }^{14}$ In 1865 both István Rakovszky and Flóris Rómer mention the dismantling and reconstruction of the tower in earlier centuries, and the walling up of the openwork spire. According to Rakovszky, the reason for this was an earthquake in the 18 th century, ${ }^{15}$ in contrast, Rómer mentions 16th-century conflagrations and an earthquake. ${ }^{16}$

${ }^{14}$ SN: Franziskanerkirche zu Preßburg. In: Publicationen des Vereines "Wiener Baubütte". Original-Reiseaufnahmen, 1, 1862.

${ }^{15}$ RAKOVSZKY, I.: Pozsony egyházai. In: Magyar Sion, 1865, pp. 206-212, p. 208.

${ }^{16}$ RÓMER 1865 (see in note 10), p. 286-287. 


\section{Building history}

At the time of the writing of this article it is widely accepted in the literature that the tower was built around $1400 .{ }^{17}$ This dating goes back to the works of Jaroslav Bureš. Since there aren't any contemporary written sources available about the construction of the tower, this date was mainly based on the similarities of the tower to some parts of the Stephanskirche in Vienna. ${ }^{18}$ By the time of the publication of Bureš's articles, Meister Michael, the master builder of the Austrian princes, was considered one of the master builders of the Stephanskirche. Bureš considered the aforementioned dome shape as original, so it served as another connection to the oeuvre of Meister Michael, because this shape is characteristic for him. ${ }^{19}$ Since then it has become known that no parts of the Stephanskirche can be connected to Meister Michael, ${ }^{20}$ and the Pressburg spire was not dome-shaped, so these aspects cannot be used for the dating.

Several authors mention that the construction of the Pressburg tower and St. John's chapel could be related to each other. ${ }^{21}$ (Fig. 4.) The literature traditionally dates the completion of the chapel to around 1400 as well, although a written source from 1361 already mentions the construction. ${ }^{22}$ So, according

${ }^{17}$ ČERNÁ-STUDNIČKOVÁ, M.: A művészeti élet és kapcsolatai Pozsonyban, Zsigmond király uralkodása idején. In: Ars Hungarica, 12, 1984, no. 1, pp. 29-49, p. 41; ed.: Magyarországi müvészet 1300-1470 körül. MAROSI, E. Budapest 1987, p. 516-517; MAROSI, E.: A koldulórendi építészet Magyarországon. In: Koldulórendi építészet a középkori Magyarországon. Tanulmányok. Budapest 1994, p. 58; POMFYOVÁ, B.: Bratislava, Kostol Nanebovzatia Panny Márie a veža františkánskeho kláštora. In: Gotika. Dejiny slovenského výtvarného umenia. Bratislava 2003. Most recently Pomfyová mentions the possibility of an earlier construction date. POMFYOVÁ 2019 (see in note 7), p. 728.

${ }^{18}$ BUREŠ, J.: On the Beginnings of Late Gothic Architecture in Slovakia. In: Ars, 2, 1968, no. 1, pp. 91-110, p. 92-93; BUREŚ, J.: The Castle Church in Kremnica and the Problem of Michael Chnab's Architectural School in Slovakia. In: Ars, 4, 1970, no. 1-2, pp. 109-144, here pp. 134-136; BUREŠ, J.: Die Meister des Pressburger Domes. In: Acta historiae artium Academiae Scientiarum Hungaricae, XVIII, 1972, pp. 85-105, here pp. 89-90.

${ }^{19}$ HASSMANN 2002 (see in note 8), p. 308-309.

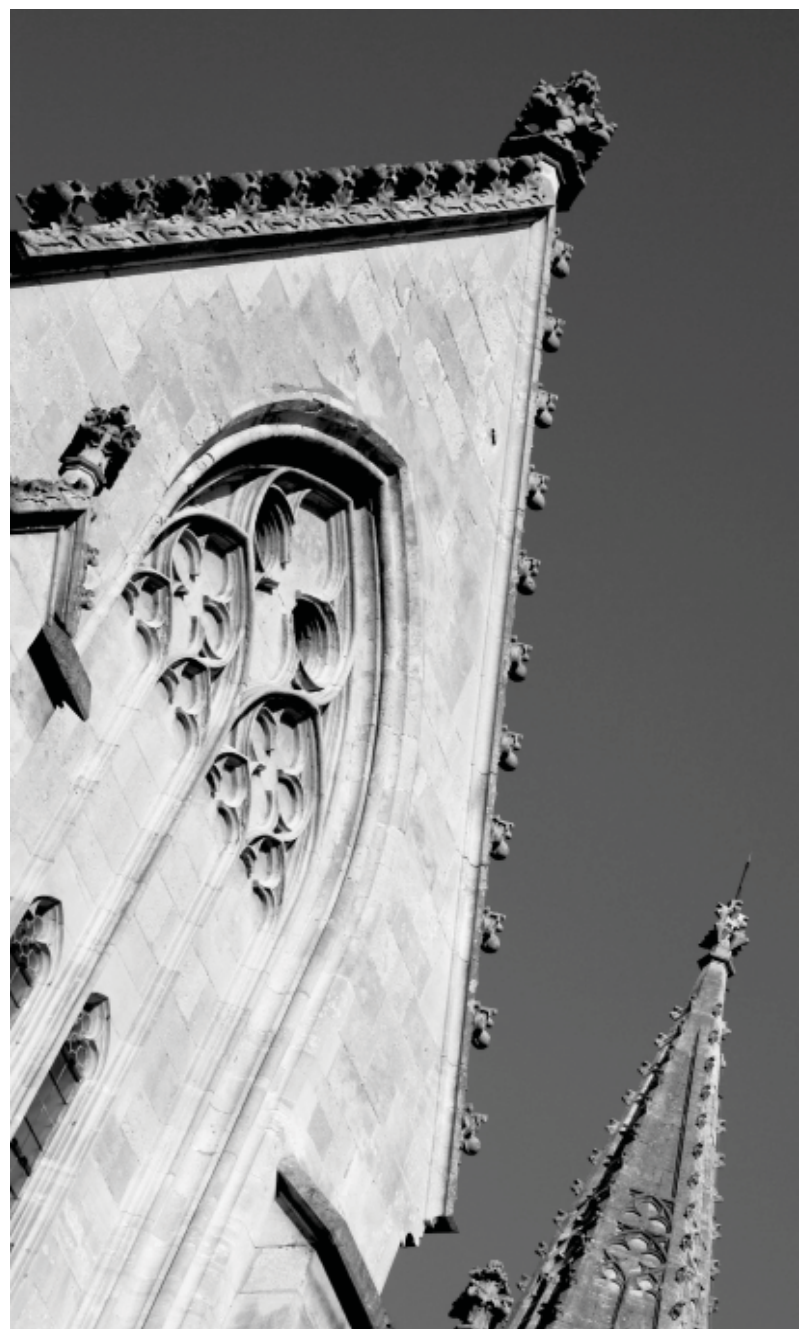

Fig. 4: The west gable of St. John's chapel of the Franciscan church in Pressburg and the spire of the church. Photo: Zoltan Bereczki

${ }^{20}$ Ibidem, p. 506.

${ }^{21}$ DIVALD, K.: Magyarorság müvészeti emlékei. Budapest 1927, p. 82; ČERNÁ-STUDNIČKOVÁ 1984 (see in note 17), p. 41; POMFYOVÁ 2003 (see in note 17), p. 624.

22 BUREŠ 1968 (see in note 18), p. 81-93; BUREŠ 1970 (see in note 18), p. 134; ČERNÁ-STUDNIČKOVÁ 1984 (see in note 17), p. 39; POMFYOVÁ, B.: Bratislava, Kaplnka sv. Jána, františkánsky kostol. In: Gotika. Dejiny slovenskébo výtvarnébo umenia. Bratislava 2003. In contrast to them, Papp Szilárd argues for one single construction period. PAPP, Sz.: Pozsony, ferences templom, Szent János-kápolna. In: Sigismundus rex et imperator. Müvészet és kultúra Luxemburgi Zsigmond korában 1387-1437. [Mainz] 2006. 


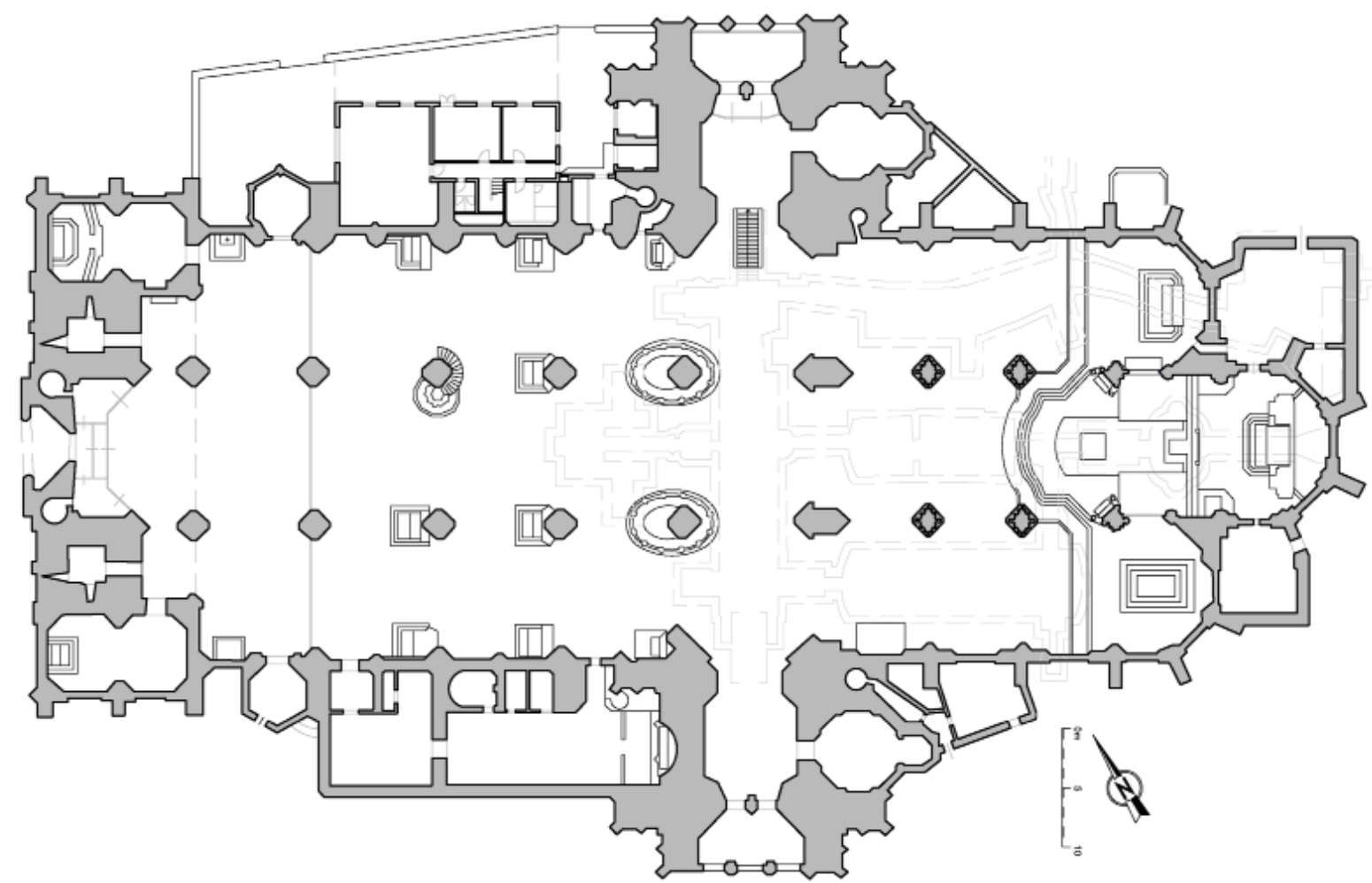

Fig. 5: Floorplan of the Stephanskirche, Vienna. Photo: https:// commons.wikimedia.org/wiki/File:St__Stephen\%27s_Cathedral,Vienna-_Plan.png

to them, the chapel could serve as another argument for the tower's dating to around 1400.

\section{The tower and St. John's chapel}

Regarding the relationship between the tower and the chapel, two questions have to be clarified. The first is the construction sequence and so the construction date of the chapel: was it built in one single campaign around 1361, or in several stages between the 1360s and 1400 ? The second is whether there is indeed a connection between the execution of the two buildings.

\section{Floor plan layout}

Although it is not recognisable at first sight due to the early modern and modern extensions and

\footnotetext{
${ }^{23}$ CIULISOVÁ 2000 (see in note 7), p. 80.

${ }^{24}$ The north tower was built much later than the south one, but
}

modifications, the tower and the chapel are situated symmetrically on the two sides of the church. (Fig. 3.) In the Middle Ages the chapel had another entrance from the church, located to the east of the current one. Directly opposite this door was another, since then also walled-up door, which led to the ground floor of the tower. ${ }^{23}$

In general, this layout resembles the floor plan of the Stephanskirche, where the ground floors of the towers open from the last bays of the nave, too. (Fig. 5.) There are two important differences, though. In Vienna the ground floors of the towers are totally opened to the nave, so they serve as a transept, and in Vienna the chapels are connected to the east side of the towers. ${ }^{24}$ The Viennese layout of the chapels looks much like a concentration of the building parts in Pressburg: there is a tower with a chapel on both

the concept was the same. SCHEDL, B.: St. Stephan in Wien. Der Bau der gotischen Kirche (1200-1500). Wien - Köln - Weimar 2018, p. 53. 
sides of the church, while in Pressburg we can find a chapel on the north side and a tower on the south side. According to Johann Joseph Böker, the model of the Viennese solution can be found in Prague, where the main elements (transept with portal and porch, tower, chapel) are also separated. ${ }^{25}$

\section{Tracery}

With only a few exceptions, practically every tracery form of the tower can be found on the chapel. The most important, most striking and very characteristic tracery form of the tower is the dropshaped quatrefoil on the spire. (Fig. 4.) This form appears on the chapel fifteen times, practically on every part of the upper chapel: on the west gable, on the windows of the nave and the choir, and in the parapets of the nave. (Fig. 4.) This drop-shaped tracery can be found on the choir of the Maria am Gestade in Vienna (finished before 1357) ${ }^{26}$ as well. Another characteristic form is the series of circles at the foot of the spire. This tracery appears in the parapets of the chapel two times, both in the choir.

\section{Baldachins}

The chapel has seven statue baldachins in the interior; all of them are different in detail, but their base forms are identical:

- hexagonal composing;

- tracery on the sides of the hexagon;

- crocketed gables with blind tracery;

${ }^{25}$ BÖKER, J. J.: DerWiener Stephansdom. Architektur als Sinnbild für das Haus österreich. Salzburg - Wien - München 2007, p. 105.

${ }^{26}$ LINSBOTH, S.: Der hochgotische Chor von Maria am Gestade in Wien - Bauintention und Nutzung. In: RIHA Journal, 0080, 2014, p. 3.

${ }^{27}$ For example, BUCHER, F.: Micro-Architecture as the 'Idea' of Gothic Theory and Style. In: Gesta, 15, 1976, no. 1/2, pp. 71-89, here p. 82; MAROSI, E.: Zum Prinzip des "Pars pro toto" in der Architektur des Mittelalters. In: Architektur des Mittelalters: Funktion u. Gestalt. Weimar 1983, p. 293. (about the parallel evolution of the baldachins and towers); BORK, R.: Rock, Spires, Paper: Technical Aspects of Gothic Spires. In: Villard's Legacy: Studies in Medieval Technology, Science and Art in Memory of Jean Gimpel. Aldershot - Burlington 2004, p. 152;
- small pinnacles on the corners;

- steep, pyramidal, crocketed termination.

All of the above are present on the tower itself. In addition to the above considerable matching in detail can also be observed.

Several authors agree that the evolution of the Gothic towers is related to the micro-architecture. ${ }^{27}$ The first proof for this statement is offered by Villard de Honnecourt himself: on the $9 \mathrm{v}$ page of his portfolio he displays the floor plan of the Laon tower together with a tabernacle similar in its structure. ${ }^{28}$

According to François Bucher, starting from the 13th century the reliquaries, stalls, fonts, pulpits, and tombs had begun to look like small buildings. "Many objects and designs from the late thirteenth century onwards show that the design theory applied to small works was identical to that used for large structures."29 "From 1350 onward the osmotic process between the three dimensional arts became more explicit." 30 This is the exact time of the "invention" of the openwork spire. About them Bucher writes the following: "They are the most spectacular expressions of the crosscurrents between macro- and micro- architecture." 31

According to Robert Bork's article on microarchitecture and spires, ${ }^{32}$ the direction of the flow of ideas changed around 1370 . Until then the microarchitecture imitated the towers, but at this time it started to happen in reverse: the ideas invented in microarchitecture began to appear on the towers. The two towers of the Chartres cathedral (south: 12th century, north: 16th century) mark the start- and

BORK, R.: Turmhelme und Kleinkunst der Parlerzeit. In: Parlerbauten-Architektur, Skulptur, Restaurierung: Internationales Parler-Symposium, Schwäbisch Gmünd, 17.- 19. Juli 2001. Stuttgart 2004; KAVALER, E. M.: Renaissance Gothic. Architecture and the Arts in Northern Europe 1470-1540. New Haven - London 2012, pp. 159-160.

${ }^{28}$ MAROSI 1983 (see in note 27), p. 286.

${ }^{29}$ BUCHER 1976 (see in note 27), p. 72.

${ }^{30}$ Ibidem, p. 74.

31 Ibidem, p. 82.

${ }^{32}$ BORK 2004 (see in note 27). 


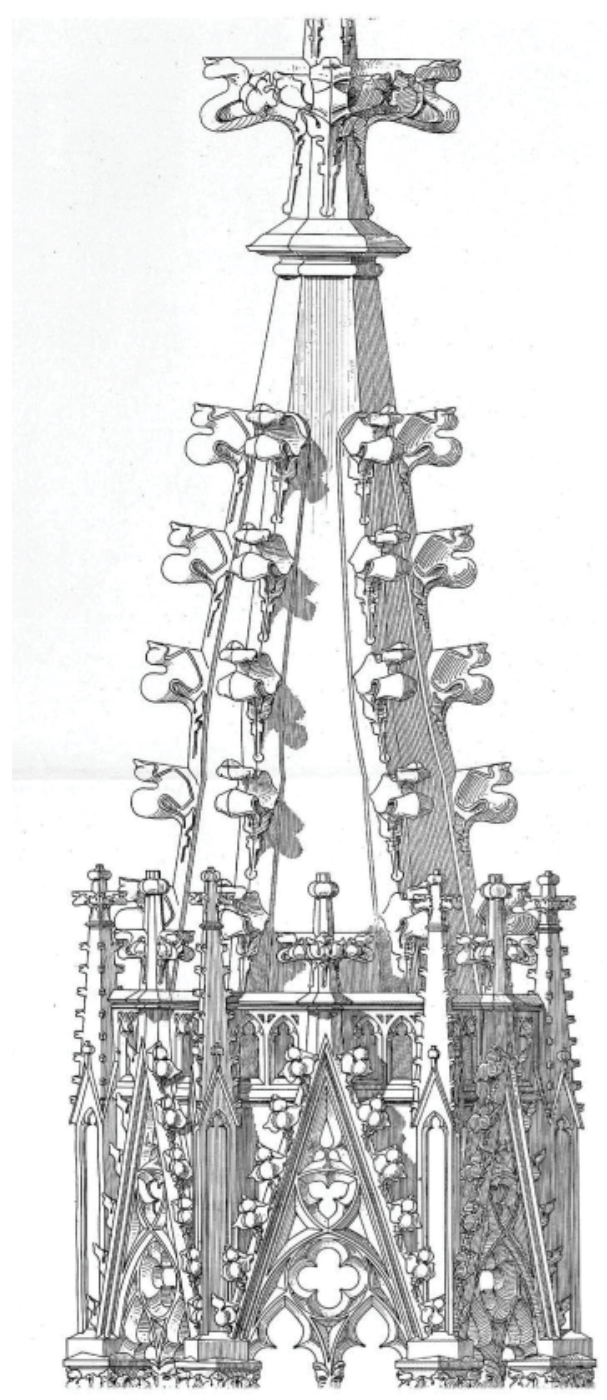

Fig. 6: Drawing of the baldachin 51 of St. John's chapel in Pressburg. Repro: HENSZLMANN 1880, p. 116

endpoints of this progress, and the Viennese south tower serves as a turning point. ${ }^{33}$

In the Pressburg chapel especially the $\mathrm{S} 1$ and the S2 are model-like. ${ }^{34}$ (Fig. 6.) On these baldachins a proportionally scaled-down version of a traced gallery can be observed. The closest parallel to this

\footnotetext{
${ }^{33}$ Ibidem, p. 195.

${ }^{34}$ In the analysis the following notation was used. North side, west to east: N1-N4; south side, west to east: S1-S3.
}

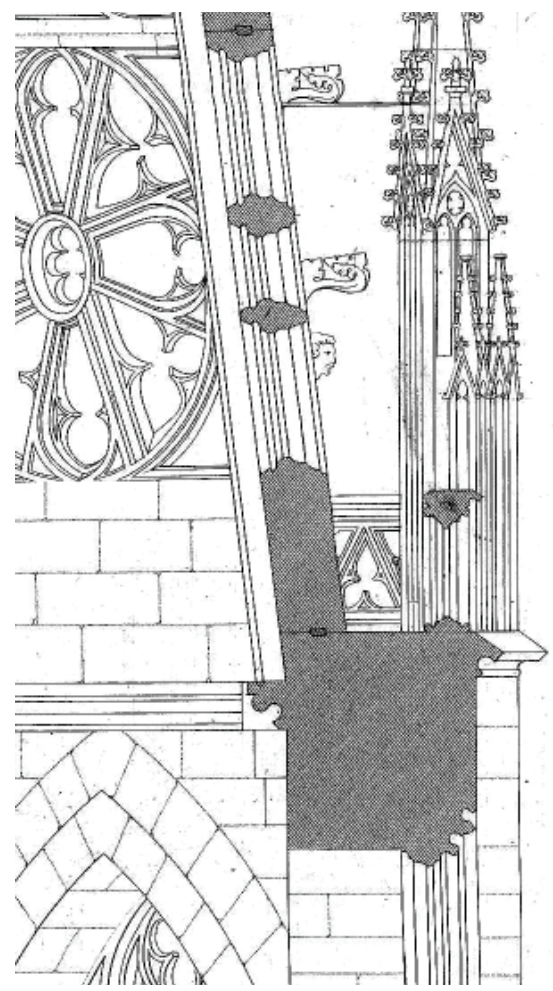

Fig. 7: Cross section of the lower part of the spire of the Freiburg Münster. Repro: MOLLER, G.: Der Muenster zu Freiburg im Breisgau. Darmstadt 1831, Taf. XI.

in macro-architecture can be found on the Freiburg tower, where a solid stone ring goes around between the topmost windows and the bottom of the spire. (Fig. 20., left) A walkable traced gallery is situated on the top of this stone ring. (Fig. 7.) The structural role of this rigid stone ring is to support the lateral forces of the spire, so only vertical forces are transferred to the octagon beneath. The gallery has also a structural role: because of it the load from the spire's edges are supported not by the external edges of the wall, as on the earlier towers, but by the internal ones, which is a better solution structurally. After the completion of the Freiburg tower, all major spires included this walkable gallery at the bottom of the spire. ${ }^{35} \mathrm{Based}$

${ }^{35}$ SCHWARZ, M. V.: Die Erfindung des gotischen Turms. Reims, Straßburg, Florenz, Freiburg, Köln. In: Ecclesia docta: Společenstvi ducha a umèni : K životnímu jubileu profesora jiř̌ho kuthana. Ed.: NESPĚŠNÁ-HAMSÍKOVÁ, M. - PEROUTKOVÁ, J. - SCHOLZ, S. Praha 2016, p. 218. 
on the above, Michael Viktor Schwarz concludes that there were three technical inventions necessary for the completion of the Freiburg spire: ${ }^{36}$

- the walkable gallery (Laufgang) around the base of the spire

- solid stone ring under the gallery

- hidden iron parts to resist tensile forces.

The two aforementioned baldachins contain very similar micro-galleries in the very same position, so the edges of the pyramid go down not directly to the edge of the 'wall', but inwards. Above the 'windows' the solid stone ring can also be found. So the creators of the baldachins copied two of the technically most important parts of the Freiburg spire. Of course, with this small size they don't have any structural role, but their presence is even more interesting this way.

The N2-baldachin is the most similar one to the Pressburg tower itself. Its gables and the flanking pinnacles are almost identical with the respective ones on the tower. Besides the main structure, the traceries, and the details, there is an important conceptual similarity. Both on the baldachin and on the tower the pinnacles flanking the gables terminate at the same height with the small pinnacle-like fleurons on the top of the gables. This phenomenon results in a "forest of pinnacles" effect: the spire emerges from a forest of 24 pinnacles, each terminating at the same height. (Fig. 2.)

\footnotetext{
${ }^{36}$ SCHWARZ, M. V.: Hoch Hinaus. Gotische Türme in Wettbewerb. In: Der Dombau von St. Stephan. Die Originalpläne aus dem Mittelalter. Wien 2011, pp. 54-55.

${ }^{37}$ For example, BUREŠ 1970 (see in note 18), p. 134; ČERNÁ-STUDNIČKOVÁ 1984 (see in note 17), p. 41; MAROSI 1987 (see in note 17), p. 516.

${ }^{38}$ ZYKAN, M.: Zur Baugeschichte des Hochturmes von St. Stephan. In: Wiener Jahrbuch für Kunstgeschichte, 23, 1970, no. 1, pp. 28-65, here p. 35.

${ }^{39}$ ČERNÁ-STUDNIČKOVÁ 1984 (see in note 17), p. 39.

${ }^{40}$ MAROSI 1987 (see in note 17), p. 154; FIDLER, P.: Das
}

\section{The interlocking gables}

The interlocking gables at the foot of the spire are the most distinctive elements of the tower. It is not an accident that the literature connects the building to Vienna based mainly on them. ${ }^{37}$ But in Vienna this motif was completed only in 1407, on the south tower. ${ }^{38}$ (Fig. 2., Fig. 20., right)

On the chapel there are not any gables with tracery, but several interlocking pointed arches can be found. Most striking is the motif on the west portal's - unfortunately only surviving in its fragments - tympanum, which is not a common form among the figural tympanums in Central Europe. ${ }^{39}$ Other interlocking arches can be observed in the parapet of the choir's north window. The tracery here is similar to the tracery in the small gables at the foot of the tower's spire.

The motif of the interlocking gables appears in Pressburg on the windows of the nearby medieval city hall, in a more basic form. (Fig. 8.) The north wing of this building was built as the dwelling house of Judge Jacob's family, and it was mentioned as new in $1370 .{ }^{40}$ This part, including a tower, belongs to the first period of the building. ${ }^{41}$ It is sure that these parts already existed by 1387 at the latest: a source from this year mentions that Paul, the son of the former Judge Jacob, pledges half of the "towered new house." 42 The windows with the interlocking gables are present only on these parts: on the tower and on the south facade of the north wing. ${ }^{43}$

So, there is no reason to assume that the immediate source of this motif is the gable of the Stephanskirche, completed only in $1407 .{ }^{44}$

Pressburger Rathaus im Mittelalter im Zeitalter der Luxemburger. In: Historia artium : Acta Universitatis Palackianae Olomucensis, Facultas philosophica Philosophica-Aesthetica, 4, 2002, pp. 213-255, here p. 213.

${ }^{41}$ FIDLER 2002 (see in note 40), p. 214.

42 ČERNÁ-STUDNIČKOVÁ 1984 (see in note 17), p. 29.

${ }^{43}$ For the theoretical reconstruction of the 1370 state, see BARRAL I ALTET, X. et al. ed.: The Art of Medieval Hungary. Roma 2018. Fig. 13.

${ }^{44}$ ZYKAN, M.: Der Hochturm von St. Stephan in Wien. Ph.D. thesis Universität Wien. Wien 1967, p. 47. 


\section{Stonemasons' marks}

From the beginning, the question of the stonemasons' marks belongs to the most discussed topics by researchers of Gothic architecture. ${ }^{45}$ According to Franz Bischoff, documentation and analysis of the stonemasons' marks on a building makes it possible to distinguish the different phases of construction and workshops, to establish a relative chronology, and to reveal some workshop connections. ${ }^{46}$

Unfortunately, a comparison of the stonemasons' marks on the tower and the chapel is not without its own problems. About the marks of the tower one single page is available, including only 17 freehand sketches. ${ }^{47}$ They were recorded in 1894 in only three days, during the 19th-century reconstruction. The situation is better in the case of the chapel: in 1897 gypsum copies were made of the marks, and Dezső Várnai made drawings based on them in 1962.48

Between the recorded marks of the tower and the chapel there aren't any perfect matches, but because of the above it doesn't mean by itself that there wasn't any stonemason who worked on both buildings. However, there is a contemporary, nearby building, where some marks can be found from both the tower and the chapel: the Stephanskirche in Vienna, more specifically the ground storey of its south tower, and its choir.

It is important to note in the following comparison that the marks weren't recorded from the buildings themselves (unfortunately there wasn't an opportunity to do this), but from publications where they were displayed by sketches. So it is not sure that the similar marks are identical, and it should also be considered that these marks are relatively simple ones. However, it is telling that according to the literature, these marks (with only two exceptions) can be found only on the discussed parts of the enormous Viennese church. (Fig. 9.)

Three marks from the Pressburg tower and one mark from the St. John's chapel can be found on the

\footnotetext{
${ }^{45}$ For a relatively recent summary of the research history, see BISCHOFF, F.: Burkhard Engelberg: "Der vilkunstreiche Architector und der Statt Augspurg Wercke Meister”. Augsburg 1999, p. 376-382.

${ }^{46}$ Ibidem, p. 388.
}

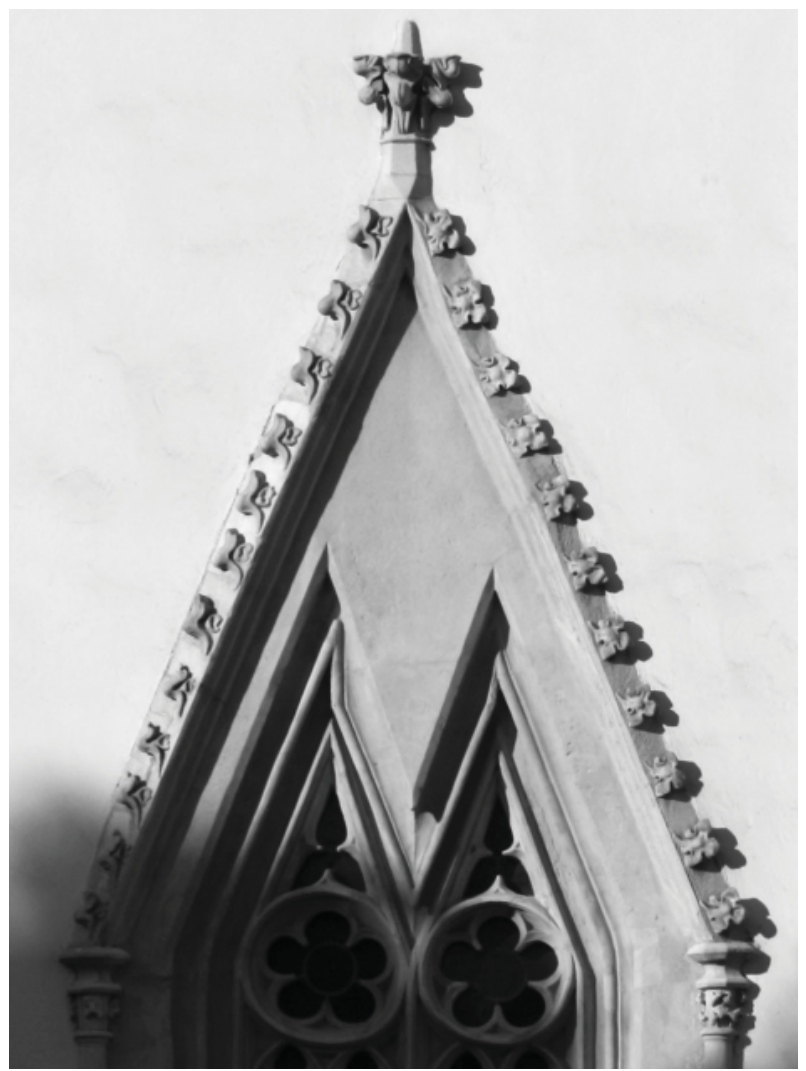

Fig. 8: Window on the tower of the Old Town Hall of Pressburg. Photo: Zoltán Berec₹ki)

ground floor of the Viennese tower. A relatively basic mark from the Pressburg tower can be found on a higher level of the Viennese tower (over the so-called Türmerstube); this is one of the aforementioned two exceptions. Four marks from the Pressburg tower and three marks from the St. John's chapel can be found on the choir in Vienna.

The beginning of the Viennese tower's construction is connected to Rudolf IV (the Stifter), who ruled between 1358 and 1365. It is not exactly known what parts of the building were finished before his death, but it is likely that the walls already stood at a

${ }^{47}$ Gyula Forster National Centre for Cultural Heritage Management, Archive for Plans, Folder of the St. John's chapel(!), drawing no. K 2044.

${ }^{48}$ VÁRNAI, D.: Pozsony (Bratislava) ferences templom melletti Szent János evangélista kápolna kőfaragó jelei, 1361-1370. In: Müemlékvédelem, 17, 1973, No. 4, pp. 199-201. 


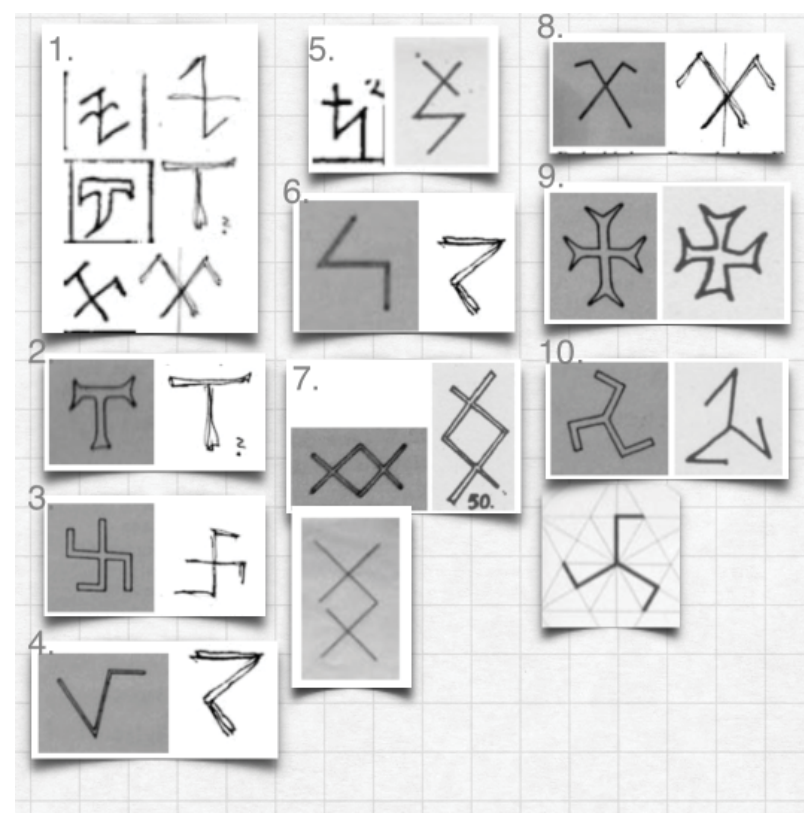

Fig. 9: Comparison of stonemasons' marks in Vienna and Pressburg: 1. Left column: Stephanskirche, exterior, ground storey of the south tower (Repro: ZYKAN, M.: Der Hochturm von St. Stephan in Wien. Ph.D. thesis Universität Wien. Wien 1967, pp. 56-59); right column: Pressburg, Franciscan tower. Photo: Gyula Forster National Centre for Cultural Heritage Management, Archive for Plans, Folder of St. John's chapel, drawing no. K 2044

2. Left: Stephanskirche, exterior, Mittelchor, Apostelnchor (Repro: KIESLINGER, A.: Die Steine von St. Stephan. Wien 1949, pp. 169170); right: Pressburg, Franciscan tower. Photo: Gyula Forster National Centre, drawing no. K 2044

3. Left: Stephanskirche, exterior, Apostelnchor. Repro: KIESLINGER 1949, p. 170); right: Pressburg, Franciscan tower. Photo: Gyula Forster National Centre, drawing no. K 2044

4. Left: Stephanskirche, exterior, Mittelchor, Frauenchor. Repro: KIESLINGER 1949, pp. 169-170.), right: Pressburg, Franciscan tower. Photo: Gyula Forster National Centre, drawing no. K 2044 5. Left: Stephanskirche, exterior, ground storey of the south tower. Repro: ZYKAN 1967, pp. 56-59; right: Pressburg, St. John's chapel. Repro: $V A R N A I, D$.: Pozsony (Bratislava) ferences templom melletti Szent János evangélista kápolna koófaragó jelei, 1361-1370. In: Müemlékvédelem, 17, 1973, No. 4, p. 200

6. Left: Stephanskirche, staircase of the south tower, over the Türmerstube.

Repro: KIESLINGER 1949, p. 173; right: Pressburg, Franciscan tower. Photo: Gyula Forster National Centre, drawing no. K 2044

7. Left: Stephanskirche, exterior, Mittelchor, Apostelnchor. Repro: KIESLINGER 1949, p. 169, 171; right: Pressburg, St. John's chapel. Repro: VÁRNAI 1973, p. 201; bottom: Vienna, Maria am Gestade. Repro: LINSBOTH, S.: Maria am Gestade in Wien. Architektur, Ausstattung und Entwicklung eines hochgotischen Chores. Msc thesis Universität Wien. Wien 2012, p. 103

8. Left: Stephanskirche, exterior, Frauenchor. Repro: KIESLINGER 1949, p. 170); right: Pressburg, Franciscan tower. Photo: Gyula Forster National Centre, drawing no. K 2044

9. Left: Stephanskirche, Apostelnchor, exterior and interior. Repro: KIESLINGER 1949, p. 170, 172; right: Pressburg, St. John's chapel. Repro: $V A R N A I$ 1973, p. 200

10. Left: Stephanskirche, exterior, Franenchor. Repro: KIESLINGER 1949, p. 169, 170; right: Pressburg, St. John's chapel. Repro: VARNAI 1973, p. 200; bottom: Vienna, Maria am Gestade. Repro: LINSBOTH 2012, p. 103

height of several meters. ${ }^{49} \mathrm{By} 1396$ the construction reached the height of the main cornice. ${ }^{50}$

The presence of the marks from Pressburg on the Viennese (so-called Albertinischer) choir seems surprising at first sight, because it is known from contemporary sources that this part of the church was already consecrated in $1340 .{ }^{51}$ But the most recent literature has proven that the building of the

${ }^{49}$ SCHEDL 2018 (see in note 24), p. 74.

${ }^{50}$ For the building history of the tower see ZYKAN 1967 (see in note 44), ZYKAN 1970 (see in note 38).

${ }^{51}$ BUCHINGER, G. - PICHLER, G.: Wien. I. Bezirk - Innere Stadt (Dehio-Handbuch). Horn - Wien 2003, p. 166. choir continued even after the middle of the century, and the building part was completed in its entirety only in $1365 .^{52}$

According to Papp Szilárd, the closest artistic parallel to the Pressburg chapel is the choir of the Maria am Gestade in Vienna. ${ }^{53}$ This building part was completed already in $1357,{ }^{54}$, and it has close workshop connections to the choir of the Stephans-

52 SCHEDL, B.: Der beschwerliche Weg zum Dom. In: Der Dombau von St. Stephan. Die Originalpläne aus dem Mittelalter. 2011, p. 32; SCHEDL 2018 (see in note 24), p. 48, BÖKER 2007 (see in note 25), p. 74-94.

${ }^{53}$ PAPP 2006 (see in note 22), p. 121.

${ }^{54}$ LINSBOTH 2014 (see in note 26), p. 3. 
kirche, as it is proven by stonemasons' marks as well. ${ }^{55}$ Furthermore, one mark in the choir of the Maria am Gestade can be found on the tower of the Stephanskirche. ${ }^{56}$

Among the known marks of the Maria am Gestade there are two which can be found both on the Pressburg chapel and the Albertinischer choir. Unfortunately, it is not known whether these marks are from the choir or from the nave. ${ }^{57}$

\section{Masonry}

Examination of the masonry of the chapel can help to clarify whether the chapel was built in one single campaign or not. The horizontal joints run around the whole building without any breaks, interruptions or shifts. Besides this, another characteristic feature of the joint structure also supports the theory of the single construction campaign. The joints between the voussoirs of the pointed arches are running horizontally to a certain height, and only above this height do they run radiantly. This characteristic can be observed on every arch of the chapel: on the crypt, on the nave and on the choir, and even on the tympanum of the portal.

It is important to note that the arches on the already-mentioned parts of the Viennese church (the ground floor of the tower, the connected St. Catherine's chapel, and the choir) were constructed in a similar way. By itself it doesn't prove a workshop connection, since it is a general technique, but it can be used as a clue, because - based on the author's observations - this kind of arch can be found almost exclusively on these parts of the church.

Another distinguishing feature of the chapel's stonework is that the blind traceries in every parapet are carved from a single stone. This characteristic can be found on every plate with blind tracery.

In conclusion, the on-site observations have proven Papp Szilárd's statement that the chapel is a

\footnotetext{
${ }^{55}$ Ibidem, p. 4, 9.

${ }^{56}$ Ibidem, p. 20.

${ }^{57}$ Ibidem, p. 21; LINSBOTH, S.: Maria am Gestade in Wien. Architektur, Ausstattung und Entwicklung eines hochgotischen Chores. Msc thesis Universität Wien Wien 2012, p. 103.
}

totally unitary building, in its fabric, its joint structure, and its architectural details. ${ }^{58}$

On the Pressburg tower the blind traceries of the gables and the zone of the circles above them are similarly constructed, with larger monolithic stones. However, the aforementioned characteristic joint structure of the chapel's arches cannot be observed on the tower.

\section{Dating, donation, authorship}

Based on the above, it can be safely claimed that the construction of the chapel and the tower were related to each other.

The full sameness of the two lodges cannot be proven because of the partial differences in the masonry and the missing stonemason's marks, but the connection between the two buildings can be clearly demonstrated. A contemporary written source indicates that the chapel was already under construction in $1361,{ }^{59}$ and all of its details and masonry testify, that it was built in one single campaign. It was also shown by Papp Szilárd that a stylistic analysis of its forms also gives no reason to place the construction to a later date. ${ }^{60}$ So there is no reason to assume that the tower was built much later (around 1400, assumed by the literature). The forms of the tower support this as well: none of them justify a dating of 1400. The most plausible conclusion is that the tower was built either together with the chapel, or right before or after it. The differences in the masonry and the stonemasons' marks work against the theory of the parallel construction, i.e., an identical workshop. Since the forms of the chapel are more advanced, the most plausible conclusion is that the tower's construction predated the chapel's, so it can be dated to the 1350s.

This new, much earlier dating can explain the similarities of the tower and the chapel to some artwork of the Visegrád castle from the time of the

\footnotetext{
${ }^{58}$ PAPP 2006 (see in note 22), p. 120.

${ }^{59}$ Bratislava City Archives, Lad. 5. No 179; LEHOTSKÁ, D.: Archiv mesta Bratislavy: Inventár stredovekých listín, listov a iných príbuzných pisomností. Bratislava 1956, No. 187.
}

${ }^{60}$ PAPP 2006 (see in note 22), p. 121. 
reign of Louis I (1342-1382). Both Ernő Marosi ${ }^{61}$ and Gergely Buzás ${ }^{62}$ recognised these similarities, but they rejected the possible workshop connections because of the later dating of the monuments in Pressburg.

The building of the chapel can be connected to the family of the Judge Jacob. It is testified by their coat of arms on the keystone of the crypt, ${ }^{63}$ and the aforementioned written source. In this charter it can be read that a particular Iohannis Iacobi, who is buried in the Franciscan church and for whose salvation the chapel is built, left his heirs a bath and an allod; and the heirs sell this inheritance to Judge Jacob for 150 denars, and they declare that they will spend this money on the construction of the chapel. ${ }^{64}$ According to the family tree of the Jacobs (reconstructed by Darina Lehotská), Iohannis Iacobi was the uncle of Judge Jacob, the granter of the charter. ${ }^{65}$

The construction of the very high quality (burial) chapel was certainly a demand for representation. The family maintained close ties with the aristocracy, and even with the royal family. ${ }^{66}$ Judge Jacob, the granter of the charter had extensive business interests in his life, and he died in 1373 as a wealthy person. ${ }^{67}$

One of his business partners, Jans (Hans, Hanns) Poll could serve as a Viennese connection. He came from a noted Viennese patrician family, and he was member of the city council of Vienna (Ratsherr) two times (in 1344 and in 1359). ${ }^{68}$ By this time, despite

${ }^{61}$ MAROSI, E.: A 14. Századi Magyarország udvari művészete és Közép-Európa. In: Müvészet I. Lajos király korában (13421382). 1982 , p. 67.

${ }^{62}$ BUZÁS, G.: A visegrádi királyipalota Anjou-kori kôtára. Visegrád 2003, p. 29-30.

${ }^{63}$ LEHOTSKÁ, D.: Jakubovci - Bratislavská patricijská rodina. In: Bratislava. Bratislava 1967, p. 79, ČERNÁ-STUDNIČKOVÁ 1984 (see in note 17), p. 38.

${ }^{64}$ For the translation of the charter the author owes thanks to Tasi Réka and Lakfalvi Géza, for the interpretation to Érszegi Géza.

${ }^{65}$ LEHOTSKÁ 1967 (see in note 63), p. 112.

${ }^{66}$ SURÁNYI, B.: Pozsonyi bíródinasztiák a XIII-XIV. Században. In: Levéltári Közlemények, 35, 1964, pp. 173-186, here pp. 176-177. all the princely donations, the Stephanskirche was the parish church of the city of Vienna. It means that the members of the council were aware of the questions surrounding its construction, and they even participated in the development of Rudolf's concept. ${ }^{69}$

Starting from 1360 Jans Poll was citizen of Pressburg. Louis I himself granted in a charter dated to this year that Hanns Poll had become a citizen of the Kingdom of Hungary and he took him into his special grace. ${ }^{70}$ Poll lived in Pressburg from this year until his death; his testament (dated in 1375) was preserved in the city archive. ${ }^{71}$

The master builder of the tower was likely the same as the unknown master builder of the chapel. About him Papp Szilárd writes the following: „The knowledge of the master builder [...] could have originated mostly in Lower Austria, but his horizons was not limited to this area." ${ }^{72}$

It seems that the master of these buildings in Pressburg was in connection with the construction of the Stephanskirche under the reign of Rudolf IV. ${ }^{73}$ As we have seen, the Viennese connections are present in forms, masonry, stonemasons' marks, and the business connections of the donator.

An important additional parallel can be observed between the characteristic figure consoles on the portal of the Pressburg chapel and the similar motifs of the Eligiuskapelle (or Herzogenkapelle) of the Stephanskirche, built under the reign of Rudolf

${ }^{67}$ LEDERER, E.: A középkoripén₹üzletek története Magyarországon: (1000 - 1458). Budapest 1932, p. 137-138.

${ }^{6}$ SAILER, L.: Die Wiener Ratsbürger des 14. Jabrbunderts. Wien 1931, p. 216.

${ }^{69}$ SCHEDL 2018 (see in note 24), p. 64.

${ }^{70}$ LEDERER 1932 (see in note 67), p. 146.

${ }^{71}$ Ibidem, p. 148.

${ }^{72}$ PAPP 2006 (see in note 22), p. 121.

${ }^{73}$ About the question of the master of this period, see ZYKAN 1970 (see in note 38), pp. 32-44; PERGER, R.: Die Baumeister des Wiener Stephansdomes im Spätmittelalter. In: Wiener Jahrbuch für Kunstgeschichte, 23, 1970, No. 1, pp. 66-107, here pp. 76-77; BÖKER 2007 (see in note 25), p. 82-84, 99. 
Fig. 10: Floor plan of the former Franciscan church of Sopron. Repro: HENSZLMANN 1880, p. 4

IV. ${ }^{74}$ Papp Szilárd also draws parallels between the Eligiuskapelle and the St. John's chapel. ${ }^{75}$

The similarities with the Viennese tower in forms, masonry and stonemason's marks point to close Viennese connections, so it cannot be excluded that the designer of the chapel and the tower of Pressburg was the contemporary, unknown master of the Stephanskirche employed by Rudolf der Stifter, and the stonemasons were members of the Vienna lodge. The tower in Pressburg can be a very important hint about the ideas of the first master of the Viennese tower.

\footnotetext{
${ }^{74}$ Temporary sources testify that this chapel was already finished in 1366. BÖKER 2007 (see in note 25), p. 56.
}

${ }^{75}$ PAPP 2006 (see in note 22), p. 121.

\section{The tower of the Franciscan church in Sopron}

The church of the medieval Franciscans in Sopron is situated on the south side of the main square (Fö tér) and functions as a closure to the square. (Fig. 1.) Nowadays, the church and the former monastery belong to the Benedictines. The choir of the church was built at the end of the 13th century, and it is one of the most important relics of Gothic architecture in the Kingdom of Hungary. ${ }^{76}$ The church has a small nave with three aisles. The tower

${ }^{76}$ About the building history of the church and the monastery, see NEMES, A.: A soproni ferences-bencés templom és kolostor. Sopron 2011. 
is situated in the axis of the south facade of the nave; the main portal of the church opens on the ground floor of the tower. (Fig. 10.)

\section{The current state of the tower}

In the last two centuries the tower had two major reconstructions. The first, led by Storno Ferenc, took place between 1888 and 1894; the second almost exactly a century later, led by Sedlmayr János.

The documents, letters, and drawings of the Storno Nachlass kept in the Sopron Museum testify that Storno preserved the original forms of the tower. ${ }^{77}$ The necessary small-scale repairs and replacements weren't modifications, so the form and the details of the tower have remained authentic. The most important change was the replacement of the upper part of the stone spire and the balustrade of the small balcony underneath of it. $^{78}$

The next major reconstruction took place between 1984 and 1989, led by Sedlmayr János. According to his final report, ${ }^{79}$ it was a restoration without any changes in form. The most important work was again the dismantling of the top of the spire down to the small balcony, and the partial replacement of the balcony's balustrade. A structural change is the insertion of two reinforced concrete slabs in place of the wooden floors of the bell storey.

\footnotetext{
${ }^{77}$ For the time being, the drawings don't have inventory numbers. Important testimonies are a perspective drawing from 1857 which displays the injuries; the detailed survey drawings predating the reconstruction (some of them were published as a woodprint in the Mittheilungen der Central-Commission in 1863, W., K. Die gotische Benedicter-Kirche in Ödenburg. Nach Aufnahmen von F. Storno und B. Rievel. In: Mittheilungen der Kaseirl. Königl. Central-Commission zur Erforschung und Erhaltung der Baudenkmale, 8, 1863, pp. 339-347.); the official report of Storno from 1894 (Fasc. 3. Nr. 50.); and his letter to the Central-Commission in 1896 (Fasc. 3. Nr. 60.).

${ }^{78}$ CSATKAI, E.: Egykori ferences, majd bencés templom. In: Sopron és környéke múemlékei. Budapest 1956, p. 265.

${ }^{79}$ Gyula Forster National Centre for Cultural Heritage Management, Archive for Plans, 27655.

${ }^{80}$ They are published in high quality in the related volume of the Hungarian Atlas of Historic Towns (Magyar Várostörténeti Atlasz): JANKÓ, F. - SZENDE, K. - BANYÓ, P.: Sopron. Sopron 2010.
}

Summarising, it can be said that both restorations were only repairs that preserved the original form, re-creating elements where needed, but including these, the whole tower is almost entirely an original, medieval structure (except Sedlmayr's reinforced concrete slabs, of course).

Just as in Pressburg, several older images of Sopron have been preserved; the oldest of them dates to the 16th century. ${ }^{80}$ Aside from the inevitable simplifications, the tower appears fairly uniformly in all of them: the gallery of the spire and the crown of the gables are clearly recognisable.

\section{Building history}

No single contemporary source has survived which could be - even indirectly - connected to the construction of the tower. The older literature mostly dates the building to the first half of the 14th century, based mainly on stylistic parallels. ${ }^{81}$

In 1961 Házi Jenő identified the owner of the goat coat of arms, which can be seen at several spots on the church: it was the family Gaissel, important patricians of the town. ${ }^{82}$ Since then the literature has been dating the construction to between 1370 and the turn of the century. ${ }^{83}$

At the time of this writing, the consensus is the following, based mainly on the research of Bartos György ${ }^{84}$ and Nemes András: ${ }^{85}$

${ }^{81}$ For example, W 1863 (see in note 79), p. 343; GYULAI, R.: Soproni templomunk. In: A pannonhalmi föapátság története. Második korszak. A pápák és zsinatok reformáló törekvései 1243-1404. Budapest 1903, p. 273; CSEMEGI, J.: A budavári fôtemplom középkori építéstörténete. Budapest 1955, p. 160, note 158; CSATKAI 1956 (see in note 78), p. 265.

${ }^{82}$ HÁZI, J.: A soproni ferences templom jótevője. In: Soproni Szemle, 15, 1961, no. 4, pp. 308-316.

${ }^{83}$ For example, DÁVID, F.: Történeti összefoglalás. Sopron, v. Ferences templom. Tech. report, Forster Központ Tervtár 14141 1972, p. 3; Müvészet I. Lajos király korában, 1342-1382: Katalógus. Ed.: MAROSI, E. et al. Budapest 1982, p. 251.; MAROSI 1987 (see in note 17), p. 419.; BUZÁS, G.: Gótika és kora reneszáns\%. Budapest 2001, p. 63-64; SZAKÁCS, B.Z.: Soproni ferences templom és kolostor. In: Magyar Müvelödéstörténeti Lexikon. Budapest 2010.

${ }^{84}$ BARTOS, Gy:: Megjegyzések a soproni ferences templom és kolostor építéstörténetéhez. In: Koldulórendi épitészet a középkori Magyarországon. Tanulmányok. Budapest 1994. 
- 1260-1280: construction of the church: first the choir, then the nave;

- 1380-1410: construction of the tower, the vault of the nave, and the organ loft.

But thorough on-site examination of the tower, a comparison to the related buildings of the era and the region, and a closer look at the donation suggest a different dating.

\section{Stonemasons' marks}

An examination of the tower's stonemasons' marks is not without its own problems. Unfortunately, the marks were not recorded during any of the reconstructions. On the locations which are accessible without scaffolding, the author managed to find several marks, but due to the defilements of the wall and the different (modern) abrasions it is not absolutely sure that they are stonemasons' marks. Taking these constraints into account, four engravings have been recorded that, if they were really stonemasons' marks, could be interesting for the subject. (Fig. 11.)

The first can be found inside the upper octagonal storey. Parallels to it can be found between the stonemasons' marks in the Pressburg tower and Stephanskirche (on the ground level of the tower and on the choir). The second one in Sopron can be found inside the lower staircase more than once; its possible parallel is between the marks in the Pressburg tower. The third one is inside the lower staircase too, more than once. Its possible parallel is on the Viennese choir. The fourth mark is on the door frame of the lower staircase. Its parallel is on the Viennese choir as well.

\section{Dating, donation, authorship}

The widely accepted dating of after the 1370 s by Házi Jenô is based on his theory that Heinrich Gaissel was the donator. Házi assumes (without any direct proof) that the previously convicted patrician had received mercy around this time, and the con-

\footnotetext{
${ }^{85}$ NEMES 2011 (see in note 76), pp. 11-16.

${ }^{86}$ HÁZI 1961 (see in note 82), p. 24-25.
}

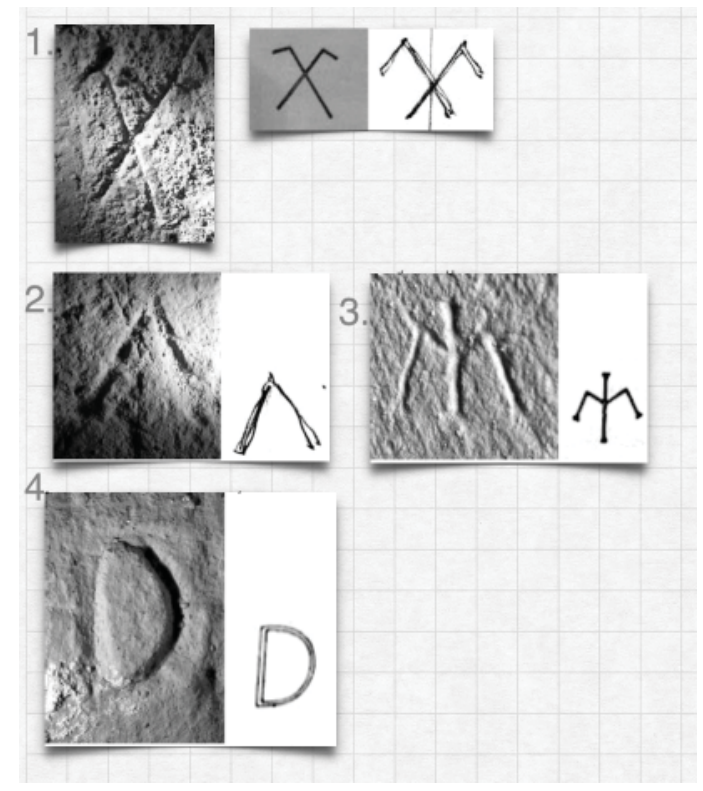

Fig. 11: Comparison of stonemasons' marks in Sopron, Pressburg, and Vienna:

1. Left: Sopron tower, upper octagon storey; middle: Stephanskirche, ground storey of the south tower. Repro: ZYKAN1967, pp. 56-59, exterior, Frauenchor. Repro: KIESLINGER 1949, p. 170; right: Pressburg, Franciscan tower. Photo: Gyula Forster National Centre, drawing no. K 2044

2. Left: Sopron tower, lower staircase; right: Pressburg, Franciscan tower. Photo: Gyula Forster National Centre, drawing no. K 2044

3. and 4.: Left: Sopron tower, lower staircase; right: Stephanskirche, upperpart of the Frauenchor. Repro: KIESLINGER 1949, p. 170

struction was his atonement. ${ }^{86}$ In contrast, the theory of Bartos György about the donation of Nikolaus Gaissel Jr. is much more reasonable and verifiable. ${ }^{87}$ He was the brother of Heinrich, in 1360/61 already the judge of the town. So the donation by itself doesn't verify the dating to after the 1370 s.

Another ground for the late dating in the literature is the stylistic resemblance of the Sopron tower to the Pressburg one, ${ }^{88}$ dated - as we have seen - in the literature to around 1400. If we accept this article's new dating for the Pressburg tower, this argument for the late dating becomes invalid. In the literature a

${ }^{87}$ BARTOS 1994 (see in note 84), p. 189.

${ }^{88}$ For example, DÁVID 1972 (see in note 83), BARTOS 1994 (see in note 84), p. 183-184. 
source from $1409^{89}$ is sometimes associated with the construction in Sopron. ${ }^{90}$ In this source, the minister of the Franciscans of Hungary and members of the Segesd chapter (Káptalan) gratefully thank the kindness of the Sopron burghers toward the order, in general. There isn't any construction activity or building mentioned.

Examining the dating from the donation, an important event is the 1366 death of Keszei Miklós, the archbishop of Esztergom. He was the brotherin-law of Nikolaus Gaissel, and the alleged donator (at this time a judge too) inherited a huge fortune. ${ }^{11}$ This could have made it possible for him to finance the construction. Taking this into account, the earliest dating for the tower must be after 1366. This is buttressed by Bartos Görgy's theory about the king (Louis I) - with whom Gaissel maintained a personal contact - as a role model for the representation. In a battle during his 1363-1366 campaign on the Balkans the king made a pledge to benefit the Mariazell church, and he founded several Franciscan monasteries along the lower Danube. ${ }^{92}$ It is unsure which parts of the Mariazell church can be connected to this pledge. ${ }^{93}$ The church has an intricate stone tower with carved spire. ${ }^{94}$ Its construction date is not known, but it is possible that it is in connection with the pledge of Louis I. Renate Wagner-Rieger dates the completion of the tower to $1387 ;^{95}$ the Dehio Handbuch dates the construction of the nave and the tower between 1359 and 1393..$^{96}$ According to Böker,

${ }^{89}$ Sopron Sz. Kir. Város Oklevéltára, Dl 384. Published in HÁZI, J.: Sopron sqabad királyi város története. 1. R. 2. Köt., Oklevelek és levelek. 1407-töl 1429-ig. Sopron 1923, p. 14-15.

${ }^{90}$ For example, HÁZI 1961 (see in note 82), p. 24; MAROSI et al. 1982 (see in note 83), p. 251; BARTOS 1994 (see in note 84), p. 187.

${ }^{91}$ NEMES 2011 (see in note 76), p. 19.

${ }^{92}$ BARTOS, Gy.: Térdelő donátor szobra. In: Sigismundus rex et imperator. Müvészet és kultúra Luxemburgi Zsigmond korában 1387-1437. [Mainz] 2006, p. 565.

${ }^{93}$ BRUCHER, G. ed.: Gotik. München - London - New York 2000, p. 270.

${ }^{94}$ Its current state is not the original. BÖKER 2007 (see in note 25), p. 103. the Mariazell tower is the realised version of the first Viennese plan, and it was completed in $1396 .{ }^{97}$ If we accept the theory that the Mariazell tower was founded by Louis I, Gaissel killed three birds with one stone with the construction of the Sopron tower: he donated an intricate stone tower (as the king in Mariazell), he supported the Franciscans (as the king along the lower Danube), and thanks to the excellent topographic situation of the church he could fulfil his representation needs in his hometown.

The stylistic analysis doesn't justify the late dating neither. The closeness of the tower, its simple, cubistic shaping, and its simple traceries are in contrast with both the Parler style of Central Europe around $1400^{98}$ and the works connected to Meister Michael (active around 1400) and his circle. ${ }^{99}$

Looking at the tower's general shape, the Freiburg impact is unequivocal. Although the Sopron spire is not openwork, its ribs on the edges are clear descendants of the Freiburg spire. They serve as load-bearing elements, so the plates between them in Freiburg can be openwork. The lack of vaults on the upper storeys connects the Sopron tower to Freiburg as well. This has a structural role too: the walls of the octagonal storey don't have to carry horizontal loads. Based on the above, the earliest possible date of the construction can be in the 1340s, because the Freiburg tower was completed around $1330 .{ }^{100}$

The most characteristic motif of the Sopron tower is its spire gallery or crow's nest (Mastkorb).

${ }^{55}$ WAGNER-RIEGER, R.: Mittelalterliche Architektur in Österreich. St. Pölten - Wien 1988, p. 161.

96 WOISETSCHLÄGER, K. - KRENN, P.: Steiermark (ohne Graz) (Debio-Handbuch). Horn - Wien 2006, p. 281.

${ }^{97}$ BÖKER 2007 (see in note 25), p. 103.

98 About this, see LEGNER, A.: Die Parler und der Schöne Stil : 1350 - 1400; europäische Kunst unter den Luxemburgern; ein Handbuch zur Ausstellung des Schnütgen-Museums in der Kunsthalle Köln. Köln 1978.

${ }^{99}$ For a list and detailed analysis see HASSMANN 2002 (see in note 8).

${ }^{100}$ BORK 2003 (see in note 3), p. 156. 
It is similar to the ones on the west towers of the Stephanskirche (Heidentürme). They are usually cited in the literature as an effect of the Stephanskirche on the church in Sopron. ${ }^{101}$ In contrast, it seems sure that this element in Sopron is older than its counterparts in Vienna. The exact building date of the west towers in Vienna is not known. Their lower parts could have been completed already in the beginning of the 13th century; ${ }^{102}$ the construction of their upper parts is usually connected to the reconstructions after the fire in $1258 .{ }^{103}$ During the restorations in the 19th century it was discovered that underneath the spires' visible stone structure a hidden glazed brick structure can be found. The external stone structure serves as a cladding on this older masonry. ${ }^{104}$ The literature dates the construction of this "Verkleidung" - including the crow's nests - to the 15th century: Rudolf Koch to the second quarter, ${ }^{105}$ Alois Kieslinger to the end of the century. ${ }^{106}$

The first known crow's nest on a Gothic spire is in Reutlingen. ${ }^{107}$ The exact construction date of this tower is not known; the literature dates it to the beginning of the 14 th century ${ }^{108}$ as one of the first followers of the Freiburg spire. ${ }^{109}$ This motif in the architecture spread widely much later, in the second half of the 15th century. ${ }^{110}$ In the wider area around Sopron there isn't any example for it from the 14th century. In contrast, on the original glazed windows of the Stephanskirche several spires are represented with a crow's nest. These windows originated in the choir, ${ }^{111}$ and the literature dates them to around 1340-1350. ${ }^{112}$ (Fig. 12.)

${ }^{101}$ CSATKAI 1956 (see in note 78), p. 265; MAROSI 1987 (see in note 17), p. 516.

102 SCHEDL 2018 (see in note 24), p. 26.

${ }^{103}$ SCHMIDT, F.: Ueber die zwei älteren Bauepochen der Domkirche zu St. Stephan (Schluß). In: Wiener Dombauvereins-Blatt, 1, 1881, no. 2-3, pp. 1-2, p. 1; BUCHINGER - PICHLER 2003 (see in note 51), p. 187.

${ }^{104}$ SCHMIDT 1881 (see in note 103), p. 2.

${ }^{105} \mathrm{KOCH}, \mathrm{R} .:$ Vorbericht zu den Bauuntersuchungen im südlichen Heidenturm von St. Stephan 1993. In: Österreichische Zeitschrift für Kunst und Denkmalpflege, XLVII, 1993, no. 3-4, pp. 129-133, here p. 133.

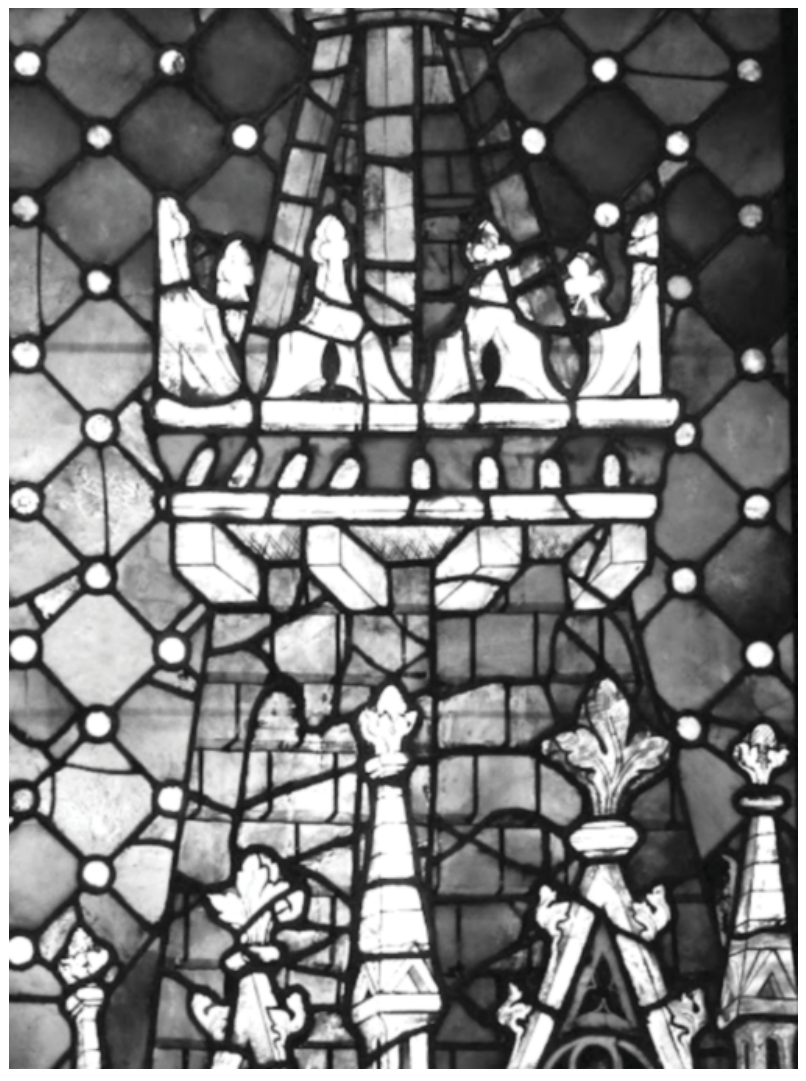

Fig. 12: Detail from an original glazed window from the Albertinischer Chor (Stephanskirche, Vienna) at the exhibition of the Wien Museum Karlsplatz: Photo: Zoltán Bereczki

${ }^{106}$ KIESLINGER, A.: Die Steine von St. Stephan. Wien 1949, p. 206.

107 BORK, R.: Gotische Türme in Mitteleuropa. Petersberg 2008, p. 20; BORK 2003 (see in note 3), p. 159. footnote 2.

${ }^{108}$ BORK 2003 (see in note 3), p. 159.

${ }^{109}$ NUSSBAUM, N.: Deutsche Kirchenbaukunst der Gotik. Darmstadt 1994, p. 379-380, note 471.

${ }^{110}$ Ibidem, p. 381, note 485 .

${ }^{111}$ Now they are stored in the Wien Museum Karlsplatz under the inventory number 48782 and 48783.

${ }^{112}$ DÜRIEGL, G.: Videňská gotika: Sochy, skelomalby a architek.tonická plastika z dómu Sv. Štěpána ve Vidni; výstava Národni Galerie v Praze ve spolupráci s Historisches Museum der Stadt Wien; Praha - Kláster Sv. Anežky české 10. Ríjen 1991 - 19. Leden 1992. [Wien] 1991, catalog item 33, 34. 


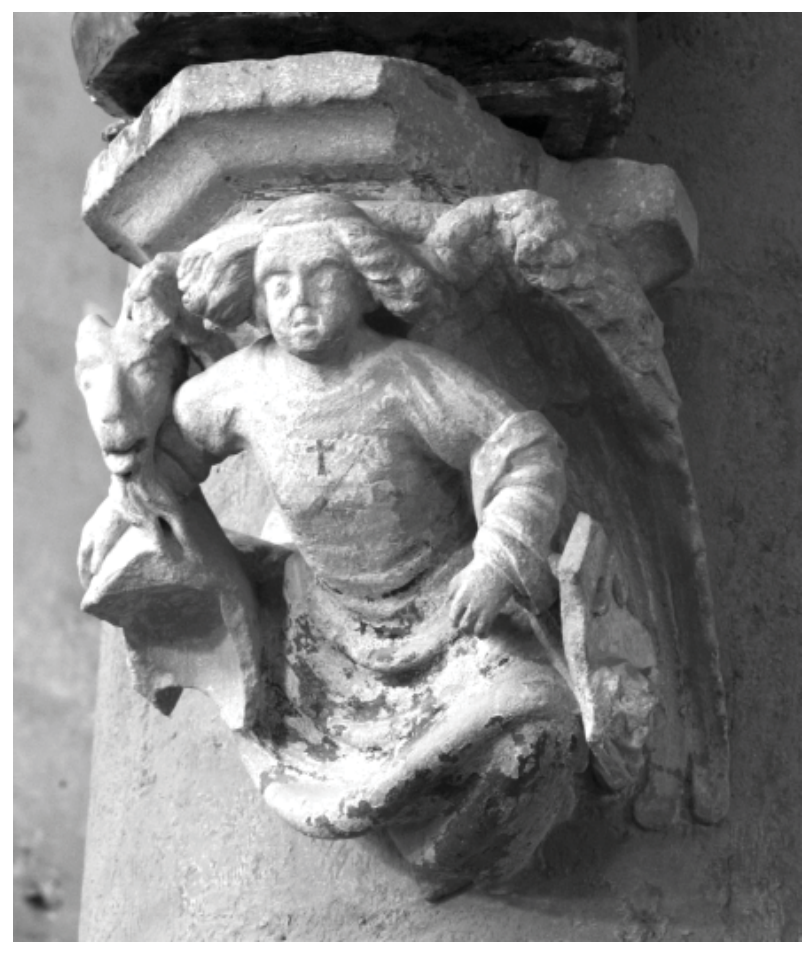

Fig. 13: Console on a pier of the nave in the former Franciscan church in Sopron. Photo: Zoltán Bereczki

The most plausible conclusion is that the motif of the crow's nest had indeed arrived in Sopron by way of the St. Stephan's workshop, but not from the west towers, as it was assumed before. Based on this, the earliest construction date of the Sopron tower shifts to the 1350 s.

It is important to mention that on Merian's relatively accurate image of Pressburg from 1683 the tower of the Clarissine Church is represented with a crow's nest. ${ }^{113}$ This spire was demolished later, and the only thing we know about the tower is that it is in close relationship with the Franciscans' tower. ${ }^{114}$ This way it can be a link between the Sopron and the Pressburg Franciscan towers.

It is very likely that the unusual position of the tower is based on the Stephanskirche. In both cases

\footnotetext{
${ }^{113}$ MENCL - MENCLOVÁ 1936 (see in note 13), p. 43.

114 POMFYOVÁ, B.: Bratislava, bývalý kostol Klarisiek. In: Gotika. Dejiny slovenského výtvarného umenia. Bratislava 2003.
}

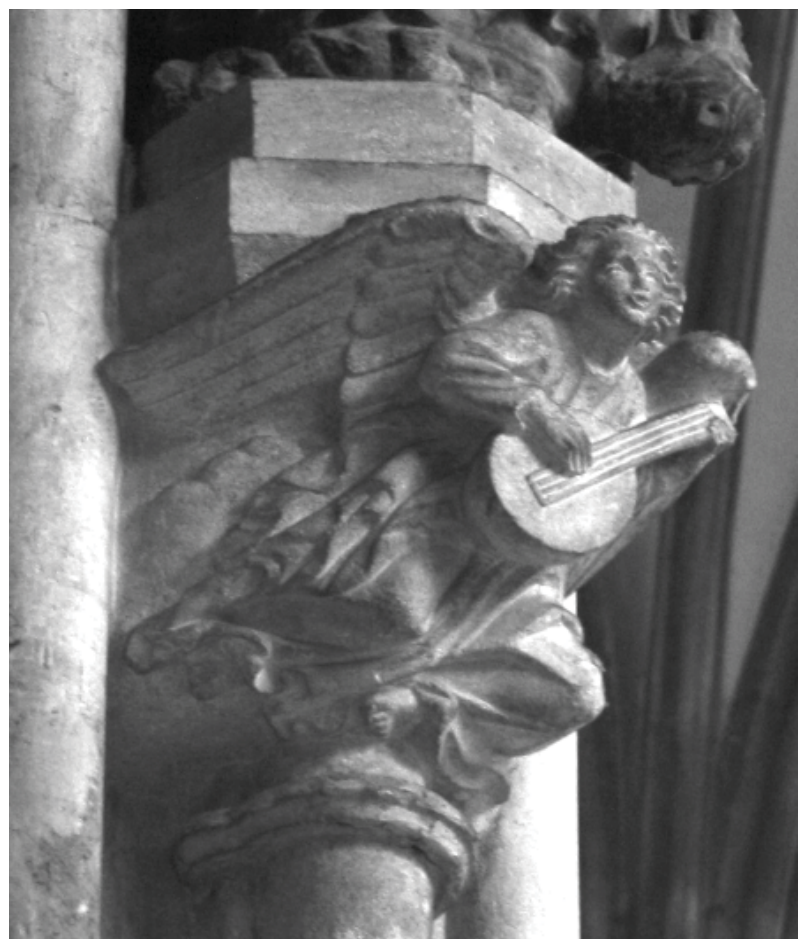

Fig. 14: Console on a pier of the choir in the Stephanskirche in Vienna. Photo: Zoltán Bereczki

the tower is situated next to the nave, and the tower has a portal and entrance to the nave. This layout created a second, north-south axis for both churches. (Fig. 5., Fig. 10.) With the tower, the Sopron church got a new main facade, facing the main square. The new, north-south axis is emphasised with the pulpit opposite the entrance and the decorated baldachins of the pillars too. ${ }^{115}$

Both Dávid Ferenc ${ }^{116}$ and Ernő Marosi ${ }^{117}$ mention the consoles of the blind arcades on the walls in the aisles of the Stephanskirche as parallels to the figural consoles on the pillars of the nave in Sopron. The similarity is very striking. In Vienna the lower parts of the external walls of the nave (Langhaus) were already completed during the reign of Rudolf IV (1358-1365) both on the north and the south

\footnotetext{
115 BARTOS 1994 (see in note 84), p. 184.

${ }^{116}$ Forster Centre, Archive for Plans, 14141.

117 MAROSI 1987 (see in note 17), p. 677.
} 
side; and the wall parts adjacent to the western chapels were already finished to the height above the windows. ${ }^{118}$ The capitols in the already mentioned Eligiuskapelle (or Herzogenkapelle) of the Stephanskirche (built under the reign of Rudolf IV) are also similar to the ones in Sopron with their double-layered foliage, but without the grotesque heads.

The figure consoles underneath the baldachins in Sopron also have their parallels in Vienna, on the pillars of the already mentioned Albertinischer choir. (Fig. 13., Fig. 14.) According to the latest research, it was entirely finished only under the reign of Rudolf IV. ${ }^{119}$ Following the usual building sequence of the Gothic, the last executed parts could be the interior pillars and the vaulting. Contemporary sources mention works on the vaults after the consecration of $1340 .{ }^{120}$

Another similarity between the Sopron and the Viennese church is the analogue profile of the portal of the Katharinenkapelle on the ground floor of the south tower in Vienna and the portal on the ground floor of the tower in Sopron.

Besides the above, the connections to Vienna are buttressed by the person of the donator as well. It is known from a 1360 source $^{121}$ that at this time Nikolaus Gaissel was the brother-in-law of a particular Johannes iudex Wÿennensis, i.e., a Viennese judge named Johannes. The person of the judge serves as a direct connection to the construction

${ }^{118}$ SCHEDL 2018 (see in note 24), p. 71.

119 SCHEDL 2011 (see in note 52), p. 32; BÖKER 2007 (see in note 25), p. 74-94; SCHEDL 2018 (see in note 24), p. 48.

${ }^{120}$ SCHEDL 2018 (see in note 24), p. 48.

121 Sopron Sz. Kir. Város Oklevéltára, D1 384. Published in HÁZI 1923 (see in note 89), pp. 14-15.

${ }^{122}$ Contemporary source, Mauerbach, Kartäuser (1266-1759) 1355 IV 20, http://monasterium.net/mom/AT-HHStA/ MauerbachOCart/1355_IV_20/charter?q=smauzzer

${ }^{123}$ SAILER 1931 (see in note 68), p. 22.

124 SZÜCS, J.: Városok és kézmüvesség a XV. Századi Magyarországon. Budapest 1955, p. 21.; KUBINYI, A.: A magyarországi városhálózat XIV-XV. Századi fejlődésének néhány kérdése. In: Tanulmányok Budapest múltjából, 19, 1972, pp. 39-56., p. 41. On the parallels and differences between the of the Stephanskirche, since, as it has been already mentioned above, the church was the parish church of the city at this time. The only person named Jans (Hans, Hanns) who was a judge around this time and was married as well is Jans I. Smauzzer. He was already married in 1355, ${ }^{122}$ and he was a judge in $1358-1359 .{ }^{123} \mathrm{He}$ could be the brother-in-law of Gaissel.

It is worth examining the possible connection between the Franciscan towers of Sopron and Pressburg. Both cities had just gone through a large economic boom at this time, followed by a stagnation. ${ }^{124}$ Examining the question from the donation the two construction campaigns are very similar: in both cases the donator is a significant burgher of the city, with good connections to the king. In both cases the representation of the nobility could serve as a pattern. ${ }^{125}$ Both towers were erected at the side of a Franciscan church, on a superb topographic position: in Sopron on the main square, in Pressburg in the direct vicinity of it. When considering the donation, it is important to mention that the construction of an ornate tower was basically alien to the Mendicant orders. According to Renate Wagner-Rieger, the tower always symbolises secular power. ${ }^{126}$

If we suppose that the Pressburg tower was erected earlier, in light of the lively relations between Sopron and Pressburg ${ }^{127}$ it is very likely that it served as a model for the Sopron one. At first sight,

evolution of the two towns in the late Middle Ages see GODA, K. - MAJOROSSY, J.: Städtische Selbstverwaltung und Schriftproduktion im spätmittelalterlichen Königreich Ungarn. Eine Quellenkunde für ödenburg und Pressburg. In: Pro Civitate Austriae, 13, 2008, pp. 60-100.

${ }^{125}$ On the relationship between the nobility and the bourgeoisie in the late medieval Kingdom of Hungary (with special emphasis on Sopron and Pressburg), see MAJOROSSY, J.: Towns and Nobility in Medieval Western Hungary. In: Mittler zwischen Herrschaft und Gemeinde. Die Rolle von Funktions- und Führungsgruppen in der mittelalterlichen Urbanisierung Zentraleuropas. Innsbruck - Wien - Bozen 2013.

126 WAGNER-RIEGER 1988 (see in note 95), p. 158.

${ }^{127}$ SZENDE, K.: Beziehungen zwischen Pressburg und Ödenburg im späten Mittelalter. In: Städte im Donauraum : Sammelband der Beiträge aus dem Symposion in Smolenice, 30. 9. - 3. 10. 1992; Bratislava - Preßburg 1291 - 1991. Bratislava 1993. 
the more decorated and originally openwork Pressburg tower seems to be the newer, but the Sopron tower is technically more advanced: it is higher and extraordinarily slender, it is vaulted only above its ground floor, it has special spiral staircases (inside the wall and sitting on a console), and it has the gallery (crow's nest) on the spire. Its technological superiority is proven by the fact that it is preserved almost in its original state, while the Pressburg one had to be reconstructed even before the 19th century. It seems likely that the reason for the closeness of the spire is not the earlier construction time but the crow's nest (which was a new invention): it had to be supported well.

There are similarities in the shape and the forms as well. The similar layout has already been mentioned. The base structure is almost identical: quadratic lower storeys with an entrance to the church; octagonal upper levels flanked by small pinnacles; a bell storey opened on all sides; a pyramidal spire with a gable crown at its base. The traceries are similar as well, even if the original traceries of the Pressburg bell storey are unknown. The most interesting tracery is perhaps that plate of the Sopron gallery which includes interlocking arches. In its base construction it is parallel to the interlocking gables of the Pressburg tower. It is worth mentioning that the parapet of the only known contemporary crow's nest in Reutlingen is totally different with its simple, geometric grid, and the supporting consoles are also missing.

The two figural consoles of the Sopron portal are parallel to the Pressburg chapel (and so the Eligiuskapelle in Vienna). Although they are not totally the same, both in Sopron and Pressburg there is on one side a male, on the other side a female head. In contrast, the aforementioned characteristic of the Pressburg chapel's arches with the horizontal joints cannot be observed in Sopron. In some places the connection of the arches to the fabric of the wall is rather irregular, it reminds one of the masonry of the Pressburg tower.

\footnotetext{
${ }^{128}$ Forster Centre, Archive for Plans, 27655.

${ }^{129}$ Forster Centre, Archive for Plans, 14141. „Beszámoló a soproni egykori ferences templom műemléki falkutatásáról és helyreállítási javaslat", p. 8.
}

The building technique of the tower is markedly distinct from the church's. The tower is built using ashlar stones, the church - including its north wall which was theoretically constructed at the same time as the tower - using rubble masonry. Although the footing of the tower continues on the wall of the nave, it stops after cca. 50 centimetres on both sides, and gives its place to the footing of the nave, which has a different profile and height.

On-site observations confirm Sedlmayr's statement that the tower is a unitary building, built in one single campaign. ${ }^{128}$ A very important observation was recorded about its construction during a building archeological examination of the walls of the nave in the 1960s. It was determined that parts of the north wall of the nave between the windows and the tower aren't unitary on either side: they separate to one part connected to the windows, and to another, with a different structure, connected to the tower. ${ }^{129}$

It is known that during the construction of the tower the north wall of the nave was demolished entirely, obviously for structural reasons: if the tower had been constructed directly next to the existing wall, they would have separated from each other because of the uneven settlement. The only way to avoid this was to pause construction after the completion of the tower until the soil settles, the movements stop, and only after that rebuild the adjacent walls of the nave. This sequence is supported both by the aforementioned observation and the statement of Sedlmayr that on the tower neither structural cracks nor sinking compared to the previous walls could be observed. ${ }^{130}$

Bartos György has reconstructed the building sequence as follows: ${ }^{131}$

- 1st phase: the construction of the two lower storeys of the tower and the adjacent segments of the north wall.

- 2nd phase: the construction of the pillars of the nave, the west balcony of the nave, the nave vault.

- 3rd phase: completion of the tower.

\footnotetext{
${ }^{130}$ Forster Centre, Archive for Plans, 27655.

131 BARTOS 1994 (see in note 84), p. 184.
} 
Based on the above, the following sequence seems more plausible:

- 1 st phase: the demolition of the north wall of the nave.

- 2nd phase: the construction of the tower in its entirety, then the construction process is suspended until the soil under the tower has settled.

- 3rd and 4th phases: the rebuilding of the north wall, the construction of the pillars of the nave, the west balcony, the nave vault.

It is possible that although the construction of the building was, according to Bartos's observations, based on a uniform concept, the tower-building workshop went away after the tower was completed, and the wall of the nave, the pillars, the west gallery, and the vaults were executed after the settling of the soil partly by another workshop. This could explain the inorganic connection of the tower's small balcony to the west gallery.

Summarising our knowledge about the donation given these stylistic, technical considerations: the architectural parallels are dated to the middle of the 14th century, and the large inheritance of the donator dates to 1366 . In this case, the second half of the 1360s seems the most likely period for the construction, and, similarly to Pressburg, the builders could be members of the Stephanskirche workshop.

\section{The two towers' position in the Gothic architecture of Europe}

\section{From Freiburg to Vienna}

"Innovative Formen kamen dadurch bereits relativ früh in weniger bekannten Zentren zum Einsatz, oft sogar bevor sie in Wien Verwendung fanden."132 This is the final conclusion of Tim Juckes's article about the construction of the nave vault of the

\footnotetext{
132 JUCKES, T.: Gewölbe der Stephanskirche. In: Wiener Jabrbuch für Kunstgeschichte, 62, 2014, no. 1, pp. 39-62, here p. 60.

${ }^{133}$ Ibidem, p. 40.

${ }^{134}$ SCHWARZ, M.: Gotische Architektur in Niederösterreich. St. Pölten 1980, p. 32.
}

135 The tower was completed in 1433 (SCHEDL 2018 [see in
Stephanskirche in Vienna. The main statement of this 2014 article is that during the long planning and construction history of the nave of the Stephanskirche, the stone masons worked at other places ${ }^{133}$ where they could try out new ideas, which later could be implemented on the vault of the nave. This statement is buttressed by contemporary drawings and documented contracts of the Viennese lodge outside of Vienna.

The situation could have been similar during the several-decade-long construction of the enormous south tower as well. As Mario Schwarz has formulated, since Rudolf IV the workshop of the Stephanskirche was under the spell of the tower question. ${ }^{134}$ However, the tower was built several decades earlier than the vault of the nave, ${ }^{135}$ so significantly fewer written and drawn sources are available related to it. So, unfortunately, this statement cannot be proven using contemporary written (or drawn) sources. However, it is conspicuous that the most important components in the appearance of the Vienna tower, which distinguish it from the Freiburg one, can be found on smaller, older towers in Vienna and its surroundings, and not only in Austria. It is important because it is generally agreed in the literature that the Freiburg tower served as a model, a paragon to the Viennese one. ${ }^{136}$

The main structure of the Vienna and the Freiburg towers is identical: quadrant lower storeys, octagonal upper storey with giant pinnacles, openwork pyramidal spire. (Fig. 20., left and right.) The most important, almost certainly conceptual difference between the two is that the main storeys and components in Freiburg are separated from each other at first sight, so the main structure is easily readable; while the Viennese tower is almost monolithic at first sight, so long observation is needed to decode its main structure. This effect is referred to by Zykan

note 24], p. 107.), the vault of the nave in the 1460s. Ibidem, p. 124. The most important literature to the building history of the tower: ZYKAN 1967 (see in note 44), ZYKAN 1970 (see in note 38), BORK 2003 (see in note 3), pp. 184-218; BÖKER 2007 (see in note 25), pp. 90-131; SCHEDL 2018 (see in note 24 ), pp. 49-110.

136 ZYKAN 1970 (see in note 38), p. 63; BÖKER 2007 (see in note 25), p. 103; BORK 2003 (see in note 3), p. 191. 
as Verschleifung, Verschmelzung. In her opinion, the underlying causes of this effect are mainly the buttresses, the giant pinnacles, and the gables with tracery. ${ }^{137}$

The main structural differences between the upper storeys (above the bell house) of the two towers are the following:

- the corners of the octagon in Freiburg are spurlike, while in Vienna they are buttressed;

- the octagon in Freiburg is open on each side; in Vienna the diagonal walls don't have windows;

- the gable crown in Freiburg is in the plane of the walls, while in Vienna it is behind it, connected to the spire pyramid;

- in Freiburg pinnacles are placed only on the corners, while in Vienna they also can be found in the axis of the walls; $;^{138}$

- related to the above, in Freiburg the gallery of the spire is behind the gables and pinnacles, while in Vienna it is between them (behind the pinnacles and in front of the gables);

- the spire in Freiburg has a clear horizontal articulation, and the edges are without any interruption, while in Vienna the horizontal divisions are missing, and on the edges there are two gable crowns with their peaks on the edges;

- at the lower gable crown the Viennese spire had a slight break, so the spire had actually two storeys $;{ }^{139}$

- and, finally, a very important structural difference: the Viennese tower is much more slender than the Freiburg one, especially its spire. ${ }^{140}$

137 ZYKAN 1967 (see in note 44), p. 78.

138 The spire pyramid in Vienna emerges from a forest of pinnacles. This effect is enhanced by the giant pinnacles as well: they terminate at the same height as the smaller pinnacles of the corners, while in Freiburg they are much lower.

${ }^{139}$ Comparing the drawings made before the reconstruction in the 19th century to the reconstruction drawings of Friedrich Schmidt, it seems that this break was straightened by him. Cross section before the reconstruction: TROST, J.: Der Umbau der oberen Pyramide des Wiener Stephansthurmes. In: Allgemeine Bauzeitung, 8, 1843, pp. 5-17. Taf. XDII.; Schmidt's drawing for the reconstruction: SCHMIDT, F.: Neubau des Thurmhelmes St. Stefan. In: Wiener Baubütte, 5, 1867 , no. 2. For this observation the author owes thanks to Michael Viktor Schwarz.
In the formulation of Michael Viktor Schwarz, the Freiburg spire is like an open bird cage, ${ }^{141}$ while the Viennese one is a more closed, enormous, slender pine tree.

\section{Gaming, Maria Straßengel}

The first examples of the Freiburg-type tower in Habsburg territories are in Gaming and Maria Straßengel. ${ }^{142}$ (Fig. 15., Fig. 16.) The Gaming tower is dated to $1332-1342$ in the literature, ${ }^{143}$ the one in Straßengel to $1355-1366 .^{144}$ Both churches are related to the Habsburgs and Vienna. ${ }^{145}$

The two towers look like small-scale models of the Freiburg tower, due to their small size without the spire gallery. The Gaming tower is the older: it is not openwork yet. The Straßengel tower is reminiscent of the Freiburg one - besides the openwork spire - with its angel statues on the pinnacles of the edges too (in Freiburg the giant pinnacles carry the angel statues). Nevertheless, both small towers are slenderer than the Freiburg one, and their spire is much steeper. The slenderness and the steep spire have important structural roles.

According to Jacques Heyman, the theoretical maximum height at which a stone column would crush at its base due its own weight would be $2 \mathrm{~km} .{ }^{146}$ The tallest medieval towers are 130-140 meters high, not even close to the theoretical $2 \mathrm{~km}$ limit. The problem is that due to the modest tensile strength, the stone structures aren't able to carry large moment forces. The stone structures can easily resist

140 The ratio of the base and the height of the spire in Vienna is 1:7, while in Freiburg it is 1:3.5. ZYKAN 1967 (see in note 44), p. 228.

141 SCHWARZ 2016 (see in note 35), p. 216.

142 BORK 2003 (see in note 3), p. 191.

143 SCHWARZ 1980 (see in note 134), p. 27; BRUCHER 2000 (see in note 93), p. 273.

${ }^{144}$ BRUCHER 2000 (see in note 93), p. 252.

145 Ibidem, p. 27.

${ }^{146}$ HEYMAN, J.: The Stone Skeleton. Structural Engineering of Masonry Architecture. Cambridge-New York 1997, p. 12. Parameters used: $2000 \mathrm{~kg} / \mathrm{m}^{3}$ unit weight, $400 \mathrm{~kg} / \mathrm{cm}^{2}$ crushing stress. 


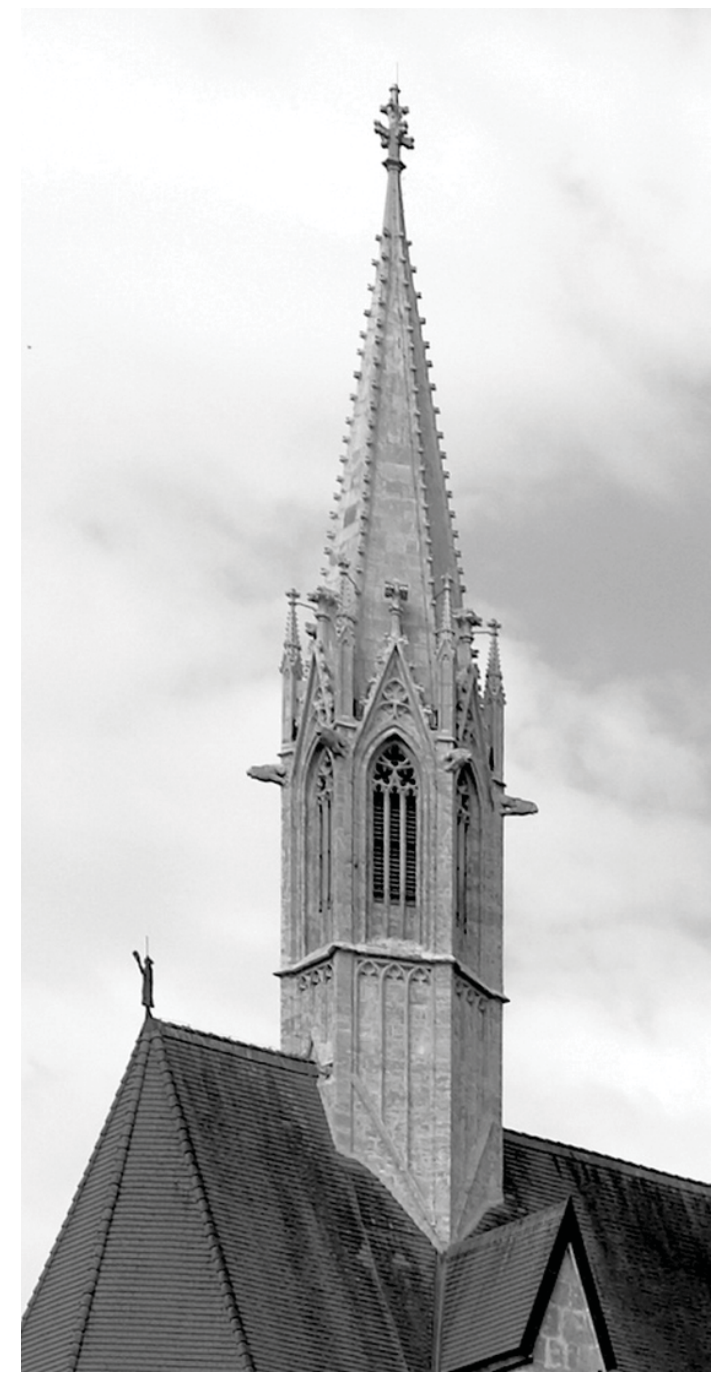

Fig. 15: Tower of the Gaming Charterhouse. Photo: https:// commons. wikimedia.org/wiki/File:Gaming___Kartause,_Torturm.JPG

Fig. 16: Tower of the church in Maria Straßengel. Photo: https:// commons.wikimedia.org/wiki/File:20150912_WikiLovesMonuments_1_17.jp

the clean vertical loads, but the arched (eg. vaults) or the inclined (eg. roofs, spires) structures induce horizontal loads too. The closer the resulting force is to the vertical, the smaller the lateral component is, i.e., the problematic horizontal load. So a slender tower is more appropriate statically than a wide one. It was made possible mainly by the slenderness of the Viennese tower and the steepness of its spire that it

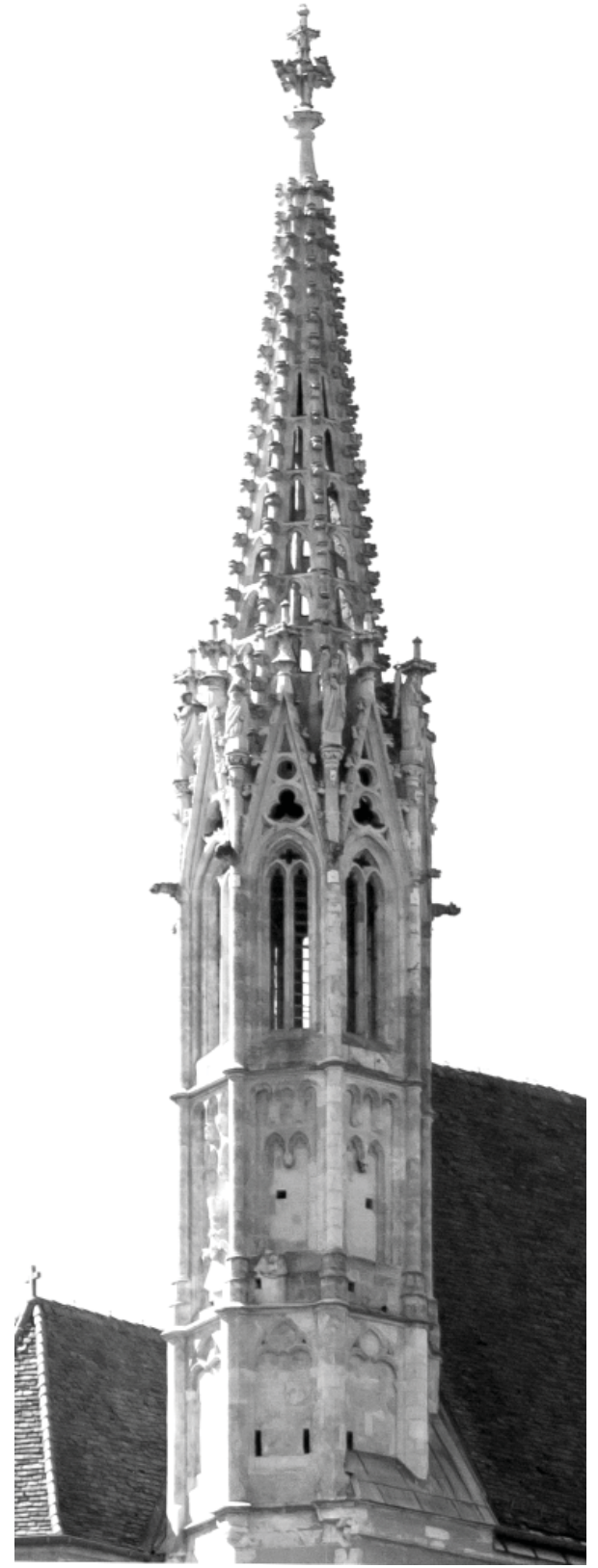

is stable without metallic reinforcement (Ringanker), unlike the Freiburg one. ${ }^{147}$

147 SCHWARZ 2016 (see in note 35), p. 216; SASS, M.: Der kühnste Turm der Christenheit: Eine statisch-konstruktive Glanzleistung des Mittelalters. In: Münsterblatt (Freiburg), 7, 2000, pp. 15-22, p. 20. 


\section{Pressburg}

There were lively connections between Vienna and Pressburg in the late Middle Ages. ${ }^{148}$ The tower of the Franciscan church in Pressburg is likely a very important stage of the development of the Viennese south tower. It enriches the Freiburg-type with a distinctly Viennese characteristic element, and several new elements appear, which we will find later on the Vienna tower.

The atypical, Vienna-like position of the tower next to the nave has already been discussed. This layout differs greatly from the layout of the other large contemporary tower projects: in Straßbourg and Cologne conventional, two-tower cathedral facades were planned, in Freiburg and Ulm the single tower is in the axis of the west facade, in Prague the tower is situated in the corner of the nave and the transept.

The most striking new element on the Pressburg tower is the area of the interconnected gables at the foot of the spire. (Fig. 2.) On the previous examples there was only one gable per side, but in Pressburg this gable is divided with two smaller ones. Double gables, which are similar also in tracery to the ones in Pressburg appear on parts of the Stephanskirche dated to the second half of the 14th century too, namely on the buttresses of the Bartholomäuskapelle and the lower parts of the tower. ${ }^{149}$

While the double gables had appeared in Vienna relatively early, the interconnected gables (smaller gables inside a larger one) were constructed only in 1407. ${ }^{150}$ Their horizontal section can be observed on the $16.819 \mathrm{v}$ drawing in the collection of the Akademie der Bildenden Künste. According to Zykan, this

\footnotetext{
${ }^{148}$ On this topic see for example OPLL, F.: Preßburg und Wien im Mittelalter - Unterschiede, Parallelen und Begegnungen. In: Städte im Donauraum: Sammelband der Beiträge aus dem Symposion in Smolenice, 30. 9. - 3. 10. 1992 ; Bratislava-Preßburg 1291 - 1991. Bratislava 1993; PERGER, R.: Beziehungen zwischen Preßburger und Wiener Bürgerfamilien im Mittelalter. In: Städte im Donauraum : Sammelband der Beiträge aus dem Symposion in Smolenice, 30. 9. - 3. 10. 1992 ; Bratislava-Preßburg 1291 - 1991. Bratislava 1993; GERÁT, I.: Kapcsolatok Bécs és Pozsony között a könyv- és a táblaképfestészet tükrében. In: Sigismundus rex et imperator. Müvészet és kultúra Luxemburgi Zsigmond korában 1387-1437. [Mainz] 2006; MAROSI 1982 (see in note 61).

149 The Bartholomäuskapelle was built between 1365 and 1370
}

15th-century drawing is a copy of an original from the third quarter of the 14 th century. ${ }^{151}$

The motif of the interconnected gables on an elevation drawing appears on a 15th-century drawing (no. 105.066) in the collection of the Wien Museum Karlsplatz. This drawing, together with the related $105.065 \mathrm{v}$, can clearly be connected to the design process of the tower. Zykan connects them to the design phase around 1407. According to her, the motif was part of the first (Rudolf IV) concept. ${ }^{152}$ In her theory Meister Wenczla (Wenzel Parler, active around the turn of the century) introduced a new concept, and inserted a second quadratic storey (the bell storey) above the first one, and abandoned the gable motif originally intended to be here. The sources first mention the carving of the stones for this gable in 1407. According to Zykan, it is likely that the new master, Peter Prachatitz put back the motif at the request of the Kirchmeister (the administrative head of the construction) and the city council. Drawing 105.066, where the gable motif is displayed relatively schematically, could be a record of this redesign. ${ }^{153}$

As it has been discussed previously, there is no reason to assume that the interlocking gables of the Pressburg tower derive directly from the Viennese ones, executed only in 1407. If we accept Zykan's theory that the gables were part of the original concept from the time of Rudolf $I V,^{154}$ then it seems likely that the architect of the Pressburg tower at least knew the first plans of the Viennese tower.

However, thorough inspection of the Pressburg tower suggests that the motif in Vienna could have been originally intended not for its current place but at the foot of the spire, as it is in Pressburg. An

(BUCHINGER - PICHLER 2003 [see in note 51], p. 187), the mentioned parts of the tower were ready before 1396 (ZYKAN 1967 [see in note 44], p. 43).

${ }^{150}$ ZYKAN 1967 (see in note 44), p. 47.

151 Ibidem, p. 56.

152 About the motif, see ibidem, pp. 172-178.

${ }^{153}$ Ibidem, p. 143-144; ZYKAN 1970 (see in note 38), pp. 5960 .

${ }^{154}$ Böker accepts this as well: BÖKER 2007 (see in note 25), p. 131. 
important, at first sight not recognisable innovation of the Pressburg tower is that the large gable is behind the small gables and the plane of the walls. In contrast, on the realised gable in Vienna they are practically on one plane. The solution in Pressburg points to the upper part of the Vienna tower, where the gallery around the spire runs in front of the gables, although the gallery is absent in Pressburg because of its smaller scale. However, the solution for water disposal is the same as on the towers with a gallery: the water from the spire flows to the downscaled equivalent of the "gallery", namely to the area between the small and the large gables, and from here it goes hidden through the bottom of the pinnacles on the external side of the gallery to the gargoyles. In Freiburg the gallery runs behind the gables, and there aren't gables directly at the foot of the spire.

According to Zykan, in the original concept the motif of the interlocking gables could have had a double function: first, the smooth transition between the quadratic and the octagonal part of the tower, secondly, the symbolism of Rudolf's distinctive crown (Zackenkrone). ${ }^{155}$ In fact, the transition between prism and octagon isn't problematic on any tower of the age, so there is no need to include such a complex element at this spot, and the perfect location of a symbolic crown would be a high position, connected to the spire, where it could be seen from anywhere. It is very likely that originally it was intended to be here, using the following solution: small gables on the external plane of the wall, the gallery behind them, and behind the gallery (connected to the spire pyramid) the large gables (as it was realised). The aforementioned elevation drawing - displaying the gable motif schematically - could be a record of the adaptation of this motif to its new position.

In addition to the pinnacles on the edges, on the Pressburg tower there is also a pinnacle on each axis of the walls of the octagon. This element is absent in Freiburg, but present in Vienna. It is also a forward-looking element in that the fleurons on the top of the gables sit on small polygonal shafts, thus

\footnotetext{
155 ZYKAN 1970 (see in note 38), p. 48.

${ }^{156}$ BORK 2003 (see in note 3), p. 202.

${ }^{157}$ For this observation the author owes thanks to Halmos Balázs.
}

serving as pinnacles. This way the spire emerges from the forest of 30 pinnacles, 24 of them terminating at the same height. This also resembles the Vienna tower: the pinnacle-forest at the base of its spire is an important effect of its appearance. ${ }^{156}$ (Fig. 20., right)

The spire in Pressburg is decorated with tracery, and originally it was openwork. When examining its masonry, an interesting anomaly can be observed. The area of the circles around the base of the spire connects to the parts above it in a quite inorganic way. ${ }^{157}$ It is particularly striking that the ribs on the edges grow thin in this area. On the archive photos it can be observed that, originally, at the drop-shaped tracery the edge ribs used to be thinner as well, although to a lesser extent. These two parts are the most similar to the structure of the Freiburg spire: they are assembled from plates, with less emphasised ribs, and without any vertical division. ${ }^{158}$

The area on the Pressburg spire between the aforementioned area of the circles and the area of the drop-shaped tracery points toward the Viennese spire: the ribs are emphasised much more than in Freiburg, and there is a pronounced division rib in the middle of the sides. The gaps of the openwork are thin, with vertical proportions. It is certain that these vertical gaps were divided somehow (on the archive photos they are filled with secondary brick masonry): either by secondary tracery or maybe by metallic bars, but almost certainly not with stone plates as in Freiburg or at the area of the circles. The rhythmic horizontal articulation known from Freiburg and Maria Straßengel is thus missing. It is important to emphasise that - similarly to the ones in Gaming and Maria Straßengel - the Pressburg spire is also steeper than the Freiburg one.

\section{Sopron}

Compared to the above three, the Sopron tower is much simpler. It looks like a simplified version of the Freiburg tower, but differs largely from it in slenderness, similarly to the Vienna tower. ${ }^{159}$

158 SCHWARZ 2016 (see in note 35), p. 219.

159 The possible connection between the slenderness of the Sopron and the Vienna towers was brought to the author's attention by Professor Michael Viktor Schwarz. 
The structural role of its slenderness can be demonstrated by the example of the tower of the parish church in Sopron (the St. Michael's church) as well. According to the literature, this tower has a workshop connection with the tower of the Franciscans, although it was built earlier. ${ }^{160}$ At the foot of its spire a small gallery can be found, similar to the one in Freiburg, but without gables; and on its spire there is a crow's nest, similar to the one on the Franciscan tower. ${ }^{161}$

In its proportions this tower is much squatter than the Franciscan one, and its spire is less steep. Sedlmayr János, who led the modern restoration of the tower, has written the following: "on the structural side the eight-side-pyramid stone spire, which was built with edge ribs and only $13 \mathrm{~cm}$ thick walls, is extremely bold." ${ }^{162}$ In the second half of the 20th century a serious structure reinforcement became necessary, and a major metallic structure had to be built inside the spire to stabilise it. ${ }^{163}$ In contrast, during the restoration of the Franciscan tower some years later, there wasn't any need to reinforce the spire, which has a similar wall thickness, but is steeper (the architect of this reconstruction was also Sedlmayr). ${ }^{164}$ Almost certainly an improved version of the parish church's spire was built on the Franciscan tower.

A baldachin of the Franciscan church is interesting from the point of view of the steep spire as well: it has an extraordinarily slender spire, resembling the "Nadelartig" Viennese one. According to the literature, these baldachins were created using the same concept as the tower. ${ }^{165}$

${ }^{160}$ CSATKAI, E.: Szent Mihály templom. In: Sopron és környékee múemlékei. Budapest 1956, p. 402-403; MAROSI 1987 (see in note 17), p. 417.

161 The stone parapets with tracery on both galleries of the St. Michael's church are the results of the 19th-century restoration by Storno.

162 SEDLMAYR, J.: Sopron, Szt. Mihály templom tornya müemlékhelyreállítás. In: Magyar Épitöipar, 33, 1984, no. 1-2, pp. 24-26, here p. 24.

163 Ibidem, p. 25.
The Sopron tower has another unusual feature which points to the early Viennese workshop: its cornice above the quadratic storeys is above the main cornice of the nave. (Fig. 1.) Both Zykan and Böker agree that it was originally intended this way in Vienna too. ${ }^{166}$

The first storey of the tower in Sopron had a large pointed-arch-shaped opening to the nave of the church. Currently, it is walled up with bricks, and its original function is not known. Due to the dark and narrow interior of the tower, it is very unlikely that - together with the connecting balcony - it had served as an oratory for the patron, as Bartos assumes. ${ }^{167}$ There are two contemporary churches in Austria where the wall of the tower is opened to the nave: one in Mariazell and one in Pöllauberg. ${ }^{168}$ The function of their openings is also obscure. Both towers were constructed in the second half of the 14th century and can be connected to the Viennese workshop. ${ }^{169}$ In contrast to the Sopron one, the position of these towers is conventional, namely, on the west side of the church. The solution in Sopron, where the wall of the tower is totally opened to the nave through a large pointed arch, structurally recalls the large pointed arch between the tower and nave in Vienna.

\section{Deutsch-Altenburg}

The tower of the parish church in Deutsch-Altenburg at first sight is the antithesis of the Viennese tower: it is a small, solid, squat, undecorated stone building with a crystal clean structure. (Fig. 17.) There

${ }^{164}$ Forster Centre, Archive for Plans, 27655., Final Report, p. 7.

165 BARTOS 1994 (see in note 84), p. 184.

166 ZYKAN 1967 (see in note 44), pp. 73-74.; BÖKER 2007 (see in note 25), p. 116. The north tower, which corrected several irregularities of the south one, was constructed this way.

${ }^{167}$ BARTOS 1994 (see in note 84), p. 189.

168 WAGNER-RIEGER 1988 (see in note 95), p. 161.

${ }^{169}$ BRUCHER 2000 (see in note 93), p. 103. 
isn't any contemporary source available about its construction, ${ }^{170}$ so all the donator, the master, and the construction time are unknown. The literature dates the tower to the middle of the 14th century, mainly because of stylistic aspects. ${ }^{171} \mathrm{It}$ is likely that it was completed already in $1380 .{ }^{172}$ Based on formal and stylistic parallels, Eckhard von Knorre lists it as an influence of the Parler workshop. ${ }^{173}$ According to Brucher the contribution of Rudolf IV's workshop cannot be excluded. ${ }^{174}$

The most important characteristic of the tower, which doesn't occur anywhere else is its basic geometric form: it is an intersection of a buttressed octagon and a quadratic prism. The rectangular buttresses around the octagon are absent in Freiburg, but present in Vienna, and they have an important role in the appearance of the tower.

In her dissertation, Marlene Zykan thoroughly analyses the horizontal sections of the Viennese tower at different heights. ${ }^{175}$ The gradient change of these is largely responsible for the so-called Verschleifung-effect. In this context, particularly important are sections no. 5 and 4, taken at the lower part of the octagon storey. On the lower section the body of the tower is still quadratic, while on the upper one it is already octagonal; and the buttresses are the same on both drawings. So, reducing the octagonal storey to its base structure, the situation is the same as in Deutsch-Altenburg: an intersection of a buttressed octagon and a quadratic prism. (Fig. 18.)

A further similarity is that the interior space in Vienna is octagonal in the quadratic storey under the octagonal one, with identical dimensions. It is the same in Deutsch-Altenburg too. In Freiburg the interior has everywhere the shape of the exterior.

Another feature, different from Freiburg but similar to Vienna, is that the diagonal sides of the octagon are closed and without windows. The structural benefit of this is obvious.

${ }^{170}$ HASSMANN 2002 (see in note 8), p. 428, footnote 913.

${ }^{171}$ WAGNER-RIEGER 1988 (see in note 95), p. 160.

${ }^{172}$ SCHWARZ 1980 (see in note 134), p. 36.

${ }^{173}$ KNORRE, E.: Von Der Kirchturm von Deutsch-Altenburg. Ein Bauwerk der Parlerzeit. In: Amici amico: Festschrift für Wer-

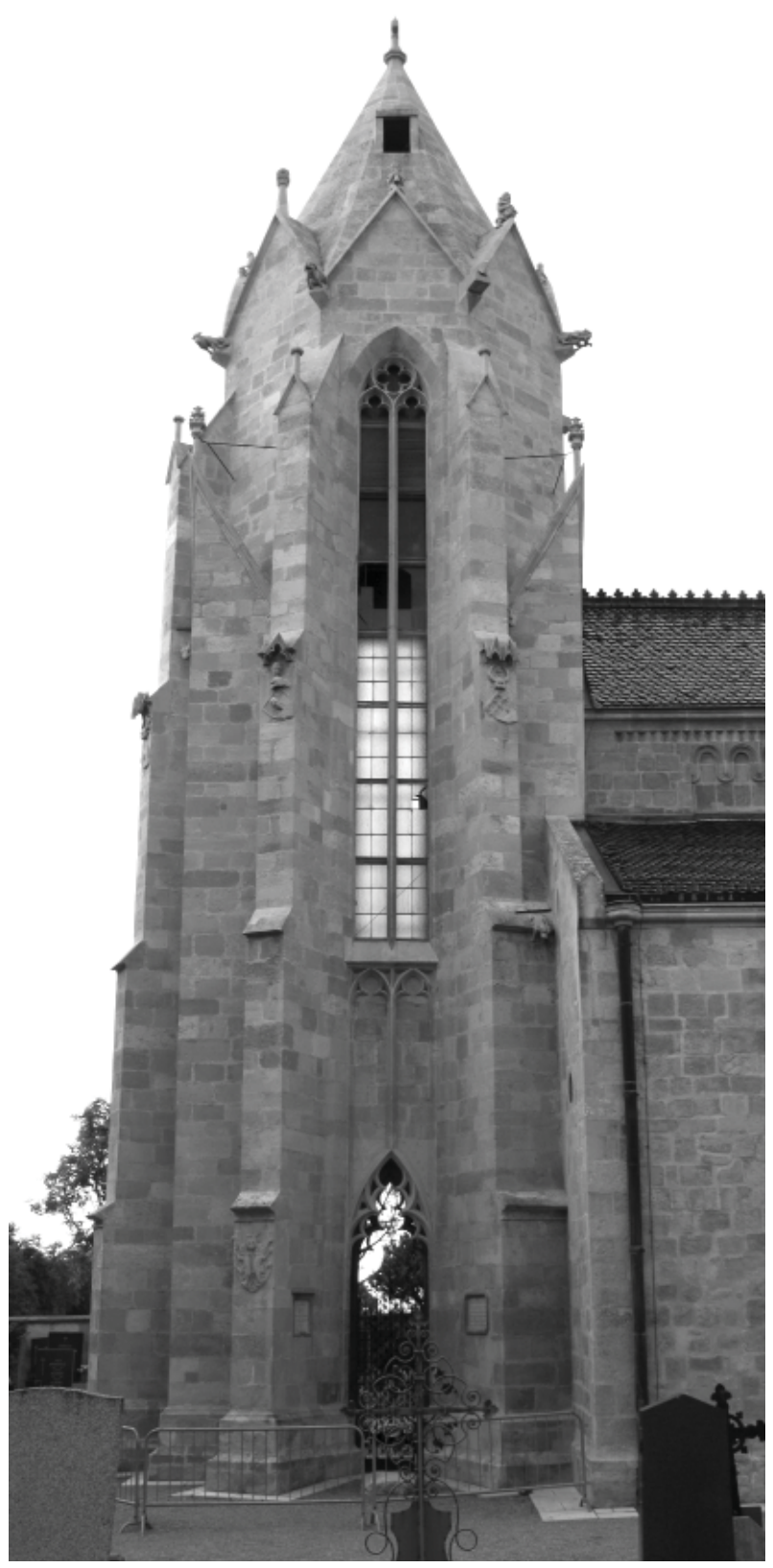

Fig. 17: The tower of the church in Deutsch-Altenburg. Photo: Zoltan Bereczki

ner Gross zu seinem 65. Geburtstag am 25. 11. 1966. München 1968.

${ }^{174}$ BRUCHER 2000 (see in note 93), p. 239.

175 ZYKAN 1967 (see in note 44), pp. 83-99. 


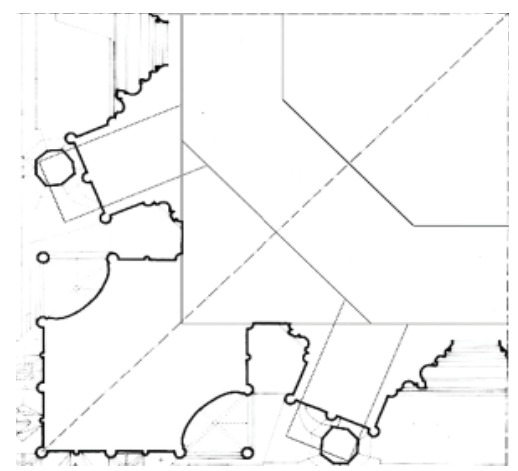

Fig. 18: Horizontal cross-section of the octagon storey of the south tower of the Stephanskirche, Vienna, (Repro: ZYKAN 1967, Abb. 34) drawn together with the base structure of the Deutsch-Altenburg tower (thin grey lines, by author). Based on DONIN, R. K. et al.: Niederösterreich (Debio-Handbuch). Horn, Wien 1976, p. 115

A characteristic element is the curtain tracery of the lower openings of the tower. It is almost identical with the tracery of the large gables in Pressburg, and its reduced version can be found on the south field of the parapet of the crow's nest in Sopron.

\section{Maria am Gestade (Vienna)}

Several architectural solutions of the church Maria am Gestade are reminiscent of the Stephanskirche, especially on the nave and the spire. ${ }^{176}$ (Fig. 19.) On the latter, every important feature of the Stephanskirche's spire can be found. The lower storeys of the tower were constructed at the end of the 1350s, the spire around 1419-1429. ${ }^{177}$

Around the spire there is the gallery. The gable crown was moved back behind the gallery, to the foot of the spire. The Pressburg-like small gables from the external side disappeared, but the pinnacles in the wall axes are present. In this way, the gallery is hidden behind the pinnacles, just like on the spire of the Stephanskirche.

A very important innovation is the gable crown on the spire, which is constructed with its peaks on the edges. This motif is the most distinctive element

\footnotetext{
${ }^{176}$ About the nave and the tower, see HASSMANN 2002 (see in note 8), pp. 216-353.
}

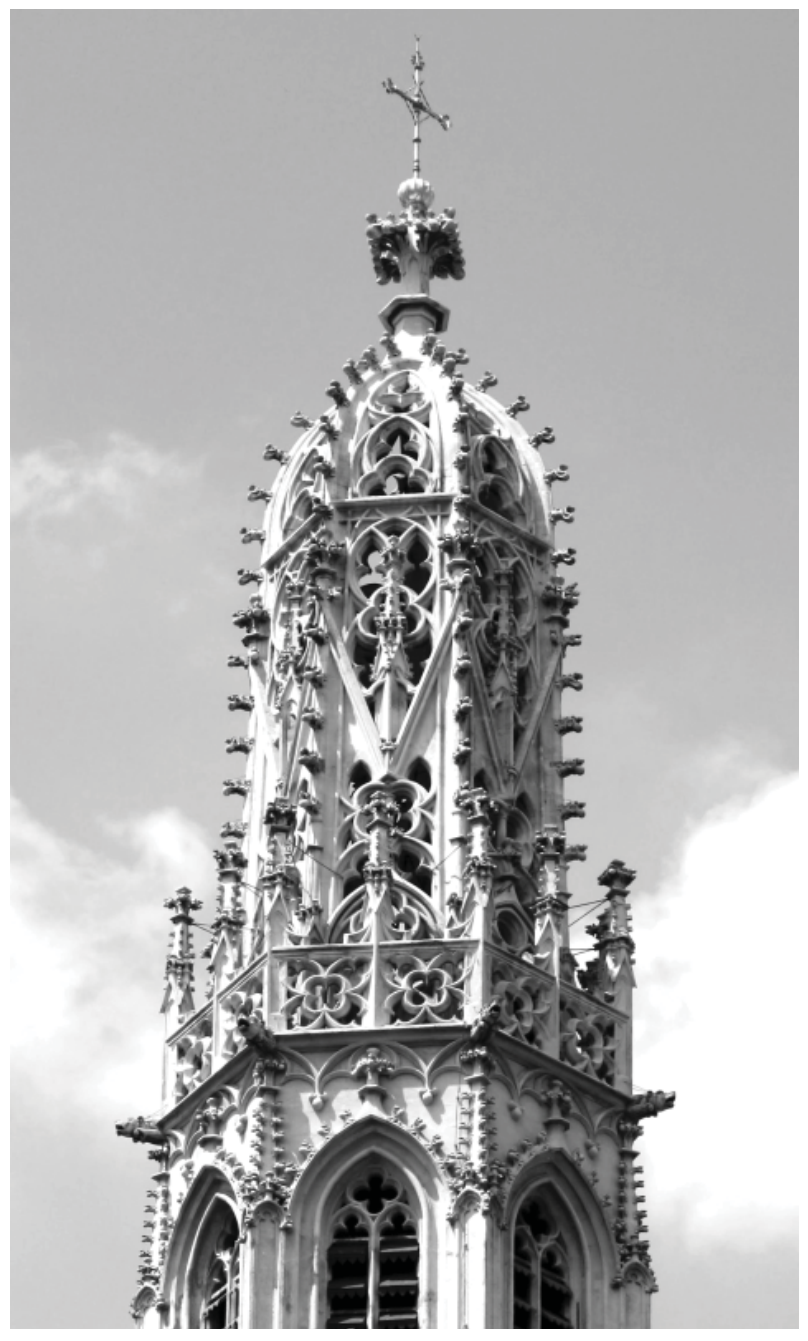

Fig. 19: Spire of the Church Maria am Gestade, Vienna. Photo: Zoltán Bereczki

of the Stephankirche's spire: it appears on it twice. These special corner gables appear on older parts of the tower as well: on the lower parts of the south tower dated around 1400, on the upper part of the stair turret, and on the buttresses of the octagon. ${ }^{178}$

Another important component of the Maria am Gestade church is its two-storey spire. The lower, straight part is followed by the upper, curved one. As

${ }^{177}$ BORK 2003 (see in note 3), p. 287.

178 ZYKAN 1967 (see in note 44), p. 232, Fig. 156, 157. 
is has been discussed earlier, before the reconstruction of the St. Stephan's spire by Friedrich Schmidt the edges of it bent at the lower gable-crown: the lower part was steeper than the upper one. This feature has an important structural role: in this way, the lateral thrust on the connecting structures is smaller. ${ }^{179}$

\section{From Freiburg to Vienna: a summary}

In 14th-century Swabia a distinctive type of St. Mary's church appeared (for example in Rottweil and Reutlingen). The churches of this type have only one tower, which is rich in detail. ${ }^{180}$ The churches discussed above fit well in this type: the parish and pilgrimage church of the Birth of the Virgin Mary in Mariazell, the Gaming Charterhouse "Marienthron", the Cistercian pilgrimage church in Maria Straßengel, the Maria am Gestade in Vienna, the church of the Virgin Mary of the Franciscans in Pressburg, the church of Our Lady of the Assumption of the Franciscans in Sopron.

But in contrast to the more regular towers in Swabia, the mostly atypical layout and the various basic forms of these towers also strengthen their experimental character. The tower in Gaming is hexagonal and - despite its stone building material - positioned as a ridge turret above the roof of the choir; the tower in Maria Staßengel is constructed above the apsis of the north aisle; the hexagonal tower of the Franciscans in Pressburg is positioned above the corner of the cloister; the pentagonal tower of the Clarissine church in Pressburg sits on consoles above a buttress of the nave; the heptagonal tower of Maria

\footnotetext{
${ }^{179}$ SCHWARZ 2013 (see in note 5), p. 6.

${ }^{180}$ WAGNER-RIEGER 1988 (see in note 95), p. 161.

${ }^{181}$ Ibidem, p. 160.

${ }^{182}$ Ibidem, pp. 158-164

${ }^{183}$ SCHWARZ 1980 (see in note 134), p. 273.

${ }^{184}$ BRUCHER 2000 (see in note 93), p. 252.

185 CSATKAI 1956 (see in note 160), pp. 402-403; MAROSI 1987 (see in note 17), p. 417.
}

am Gestade is positioned in the corner created by the choir and the nave, whose axes close an angle. Although the tower in Deutsch-Altenburg is situated conventionally on the west side of the church, originally it wasn't in connection with the nave. ${ }^{181}$

In the case of Gaming, Maria Straßengel, Deutsch-Altenburg, and Maria am Gestade, Wagner-Rieger, among others, assumed a connection to the workshop of the Stephanskirche and the south tower. ${ }^{182}$ The Franciscan towers of Pressburg and Sopron fit in these series.

According to the secondary literature the chronology of the aforementioned towers is the following:

- Gaming: 1332-1342 183

- Maria Straßengel: 1355-1366 $6^{184}$

- Sopron, parish church of St. Michael: around the middle of the 14 th century ${ }^{185}$

- Deutsch-Altenburg: middle of the 14th century, finished before $1380^{186}$

- Sopron, Franciscan church: between 1380-1409 187

- Pressburg, Franciscan and Clarissine: around $1400^{188}$

- Maria am Gestade: lower parts around 1350, spire around 1419-1429189

- Stephanskirche, south tower: foundation stone 1359, lower tracery gables 1407, gallery zone 1426/27, completion $1433^{190}$

In the case of Pressburg and Sopron this order needs correction. The corrected chronology is the following, compared to the corresponding dates of the Stephanskirche.

1. 1332-1342: Gaming

2. 1340-1350: the glazed windows of the Albertinischer Chor displaying towers with crow's nest ${ }^{191}$

186 WAGNER-RIEGER 1988 (see in note 95), p. 160; SCHWARZ 1980 (see in note 134), p. 36.

187 NEMES 2011 (see in note 76), p. 12.

188 POMFYOVÁ 2003 (see in note 17); POMFYOVÁ 2003 (see in note 114).

${ }^{189}$ BORK 2003 (see in note 3), p. 287.

190 BUCHINGER - PICHLER 2003 (see in note 51), pp. 167168.

${ }^{191}$ DÜRIEGL 1991 (see in note 112), catalog item 33, 34. 
3. 1350s: the Franciscan tower of Pressburg, based on Viennese plans ${ }^{192}$

4. 1355-1366: Maria Straßengel

5. 1359-1365: Stephanskirche, south tower, beginning of the construction, building of the lower parts

6. 1360s: Pressburg, St John's chapel ${ }^{193}$

7. Between 1365-1380: the construction of the Stephanskirche was (at least partly) in hiatus; with the participation of the Viennese workshop first the Franciscan tower of Sopron was built, then the one in Deutsch-Altenburg

8. 1407: Stephanskirche, south tower, lower tracery gables ${ }^{194}$

9. 1419-1429: the spire of Maria am Gestade ${ }^{195}$

10.1426-1427: Stephanskirche, south tower, the area of the gallery around the spire ${ }^{196}$

11.1433: Stephanskirche, south tower, completion ${ }^{197}$

12.Second quarter or end of the 15th century: Stephanskirche, the crow's nests of the west towers ${ }^{198}$

This chronology is buttressed by the stonemasons' marks too. As it has been discussed earlier in this article, the marks of the Pressburg tower appear in Vienna on the exterior of the Mittelchor and the Apostelnchor ${ }^{199}$ The marks of the Pressburg chapel can be found on the exterior of the Frauenchor; and in the interior, on the transverse ribs of the vault. (Fig. 9.) The supposed marks of the Sopron tower appear mostly on the exterior of the Frauenchor, mostly on its upper parts. (Fig. 11.) The marks of

${ }^{192}$ Although the laying of the foundation stone by Rudolf IV happened only in 1359, the plans had to have been ready earlier. SCHEDL 2018 (see in note 24), p. 64.

${ }^{193}$ PAPP 2006 (see in note 22).

194 ZYKAN 1967 (see in note 44), p. 47.

${ }^{195}$ BORK 2003 (see in note 3), p. 287.

196 ZYKAN 1967 (see in note 44), p. 52.

${ }^{197}$ Ibidem, p. 53.

${ }^{198} \mathrm{KOCH} 1993$ (see in note 105), p. 206.

199 One of them appears on an upper storey of the tower, over the so-called Türmerstube, but likely accidentally. all three buildings appear on the lower storey of the south tower.

Among these building parts, the construction of the Apostelnchor started first, then the Mittelchor and the Frauenchor. The completion of the entire choir was extended beyond the middle of the 14th century. ${ }^{200}$ In 1377 the glass from the windows of the Frauenchor was still missing, and a donation from 1390 indicates that the external walls of this building part were still unfinished. ${ }^{201}$ As for the tower, the account books suggest that the building of the first storey was completed only in $1404 .^{202}$

Construction of the south tower was very slow from the laying of the foundations in 1359 till the turn of the century. ${ }^{203}$ Böker writes that the construction was stopped after Rudolf's death in 1365 , and started again only in $1380 .{ }^{204}$ This period could have been an opportunity for the workshop to explore new methods of working at different places. The consensus in the literature maintains that originally a lower, stumpier, in its proportions also more similar to the Freiburg tower was intended to be built in Vienna as well; and the plan change could have been around $1400 .{ }^{205}$ The consensus today is that construction on the Viennese tower was started by a Viennese workshop based on an - to us unknown - original plan during Rudolf's reign, and the arrival of Wenzel Parler brought a radical change in the plan, i.e., the upper storeys of the tower were built under a different concept, whose origin can be found in the architecture of the Parlers. In the

${ }^{200}$ SCHEDL 2018 (see in note 24), pp. 46-47.

201 Ibidem, p. 94.

${ }^{202}$ Ibidem, p. 98.

${ }^{203}$ ZYKAN 1967 (see in note 44), p. 71.

${ }^{204}$ BÖKER 2007 (see in note 25), p. 105.

${ }^{205}$ BORK 2003 (see in note 3), p. 195; ZYKAN 1967 (see in note 44), p. 299.

206 ZYKAN 1967 (see in note 44), p. 260-261; BORK 2003 (see in note 3), p. 196; BUCHINGER - PICHLER 2003 (see in note 51$)$, p. 182. 
literature, the idea of the higher tower is connected to the arrival of Wenzel Parler from Prague too. ${ }^{206}$ However, based only on the realised parts of the Prague tower - due to the lack of the original plans - only very limited conclusions can be made about its planned height. In my opinion, the Gothic workshop of the Stephanskirche was, in its own right, innovative from the beginning, and experimented with its ideas on the smaller towers in the broader region. Then, these ideas were later realised on the Stephanskirche, improved and modified, even during the time of the Parlers. Although Böker writes that the upper part of the southern tower is a completely new concept, ${ }^{207}$ the appearance of several elements on the surrounding towers suggests that master Prachatitz (the master of the upper parts, member of the Parler workshop) took over elements from the original concept too.

The most important innovation in the south tower of the Stephanskirche is not simple in its appearance but in its structure as well: it is its slenderness. In contrast to what the earlier literature claims, there is no reason to suppose that this idea arrived in Vienna with the Parlers. While there isn't any information available about the planned height of the Prague tower - i.e., about its slenderness - the majority of the towers connected to the Viennese workshop are slender: the ones in Gaming and Maria Straßengel, and especially the one in Sopron; and the Pressburg spire is steeper, too, than the Freiburg one, although to a lesser extent. It is probably not a coincidence that the two earlier spires with more traditional proportions needed the most serious structural reinforcements: the one of St. Michael's church in Sopron and the one of the Franciscans in Pressburg.

Paradoxically, the greater height of the Viennese tower compared to the Freiburg one is also favorable statically. The absolute height matters because of

${ }^{207}$ BÖKER 2007 (see in note 25), p. 131.

${ }^{208}$ About the relationship between the wind load and the tower's wall thickness, see HUERTA, S.: Technical Challenges in the Construction of Gothic Vaults: The Gothic Theory of Structural Design. In: Bautechnik des Historismus : von den Theorien über gotische Konstruktionen bis zu den Baustellen des 19. Jahrbunderts: Construction techniques in the age of historicism. München 2012, pp. 187-188. stability when carrying the wind load. The wind load depends on the cross-sectional surface of the tower (the elevation area), but the weight depends (and so the resistance against the wind load) on the volume. Illustrated on the example of a cube, if we double the side of the cube, the area of a plane will be four times bigger (the square of the side length), while the volume will be eight times greater (the cube of the side length). In the case of a tower, the weight will increase significantly more than the elevation area only if the wall thickness is also scaled up parallel to the increase of the height. ${ }^{208}$ Contemporary sources testify that the Gothic practice was based on similar principles: in these manuscripts the wall thickness of a tower depends on its height. ${ }^{209}$ So if we consider a tower as a rigid structure, its stability is in connection with its height (it is more stable if it's higher). ${ }^{210}$ Summarising the above, the higher and slenderer the tower and the steeper its spire, the better it works structurally. ${ }^{211}$

Among the innovations of the early (mid-14th-century) Viennese workshop, the following ideas can be also mentioned: the motif of the interlocking gables, the forest of pinnacles around the spire, and the repositioning of the gable crown from the external side of the wall to the foot of the spire. The crow's nest of the west towers could also be the idea of this workshop, as the window paintings and the Sopron spire testify. This was eventually left out from the realised south tower, but it was realised later on the west towers. If we accept Knorre's argument about the participation of the Parler workshop on the tower of Deutsch-Altenburg, ${ }^{212}$ probably this building site was the first one around Vienna where the workshops of Vienna and Prague met. The most important invention of this tower (geometric intersection) fits well into the thinking of the Parlers, where the limits of the different building parts disappear.

\footnotetext{
${ }^{209}$ Ibidem, p. 168.

${ }^{210}$ Ibidem, p. 191.

211 The discussion of the structural role of the steepness, see above.

${ }^{212}$ KNORRE 1968 (see in note 173).
} 

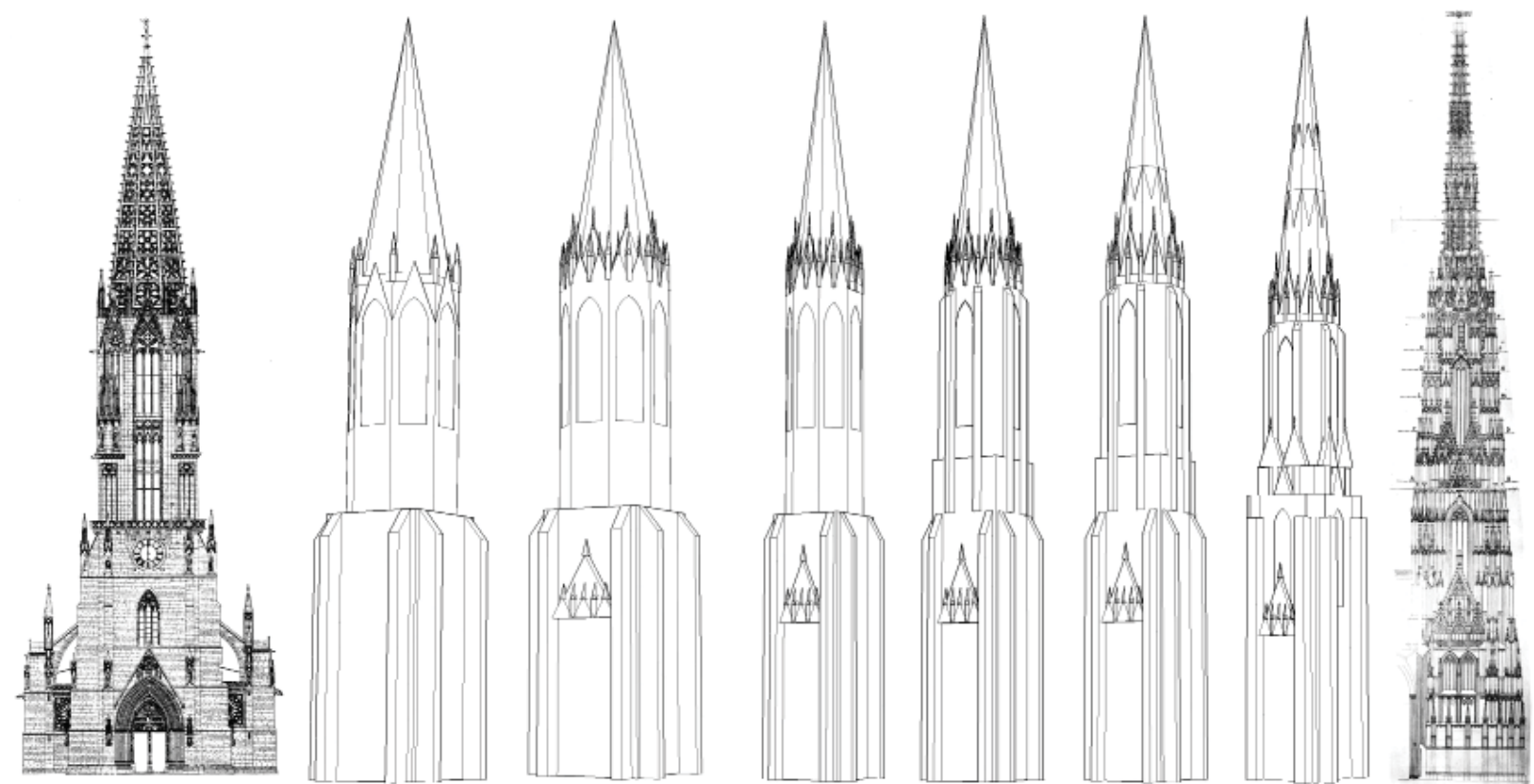

Fig. 20: From Freiburg to Vienna in schematic drawings. Left: elevation drawing of the Freiburg tower (bttps:// www. zum.de/Faecher/M/BW/ M9N/LP5/muenster.html), right: elevation drawing of the Vienna tower. Repro: ZYKAN 1967, Abb. 12. Drawings in-between: Zoltán Bereczki.

In my opinion, the realised Viennese tower is a synthesis of the ideas of the 14th-century Viennese workshop and the architecture of the later arrived Parlers; where the latter used more from the former than it was previously assumed. Two important stages of the progress are the towers in Pressburg and Sopron; the former more in its forms, the latter more in its structure.

The discussed two Franciscan towers from the Kingdom of Hungary are also important for the question of the European evolution of Gothic towers, because they were built before the age of the Parlers. When due to the general uncertainty predating the Hussite wars the operation of the Prague and Kolín Parler workshops came to an end, many stone masons wandered to neighbouring countries. In south German territories the most important question at this time was the building of towers, so in the words of Norbert Nußbaum "die süddeutschen Turmprojekte sind eine wahre Domäne Prager Formen." 213

${ }^{213}$ NUSSBAUM 1994 (see in note 109), p. 205.
In the following I would like to illustrate step by step with schematic drawings the process as the Freiburg tower transforms to the Viennese, through the components of the above-discussed smaller towers. (Fig. 20.)

An explanation of the drawings in the figure, from left to right:

0. Schematic elevation drawing of the Freiburg tower ${ }^{214}$

1. Schematic 3D model of the Freiburg tower, including the most important parts but without the giant pinnacles:

- there aren't any buttresses around the octagon, windows are present on each side;

- the gable crown is on the plane of the walls, the gallery of the spire is behind it;

- pinnacles are placed only on the corners;

- the edges of the spire are not interrupted by anything.

2. Adding the components appearing on the Franciscan tower in Pressburg:

\footnotetext{
${ }^{214}$ https://www.zum.de/Faecher/M/BW/M9N/LP5/muenster.html
} 
- interlocking gables;

- pinnacles in the axis of the walls, pinnacle-like terminations of gables, a "forest of pinnacles": pinnacles at the foot of the spire with an identical height;

- the large gable at the foot of the spire is behind the gallery around the spire.

3. Adding the component appearing in Gaming, Maria Straßengel, Sopron:

- slenderness.

4. Adding the components appearing in Deutsch-Altenburg:

- buttresses around the octagon;

- intersection of buttressed octagon and square prism;

- there are no windows on the diagonal sides of the octagon.

5. Adding the components appearing on the tower of Maria am Gestade, Vienna:

- gables at the foot of the spire are only present behind the gallery, there are no gables on the external plane of the walls;

- double-storey spire, divided by a gable crown which is constructed with its peaks on the edges of the spire;

6. Schematic 3D model of the Viennese tower, including the most important parts but without the giant pinnacles:

- the corners of the octagon are buttressed, the diagonal walls don't have windows;
- the buttressed octagon intersects with the underlying quadratic storey;

- enhancement of the interlocking gables at the connection of the quadratic and octagonal storeys, here the two buttresses per side unite in a single, diagonal one;

- the gable crown of the spire is behind the gallery, connected to the spire pyramid;

- pinnacles are present in the axis of the walls too, "forest of pinnacles": pinnacles at the foot of the spire with an identical height;

- the edges of the spire are interrupted by two gable crowns, the lower is constructed with its peaks on the edges of the spire; here the edges are bent, making the spire two-storey.

7. Schematic elevation drawing of the Viennese tower. ${ }^{215}$

\section{Acknowledgement}

During the research the author I received invaluable help and support from the following persons: Bachman Zoltán, Harry Edward Bailey, Bakó Zsuzsanna, Bereczki Dániel, Buday Péter, Érszegi Géza, Fekete Attila, Gaucsík István, Ivan Gerát, Tim Juckes, Viktor Karl’a, Lakfalvi Géza, Juraj Andrej Mihály, Nemes András, Norbert Nußbaum, Papp Szilárd, Barbara Schedl, Michael Viktor Schwarz, Sisa József, Tasi Réka, Michal Valach, Jasmine Wessely, Franz Zehetner.

\title{
The Single Gothic Towers of the Two Franciscan Churches of Bratislava and Sopron and Their Possible Connections to Vienna
}

\author{
Résumé
}

The openwork spires with their height and technical quality are the most advanced building parts of the Gothic architecture. Their first representant was constructed in Freiburg im Breisgau (completed around 1330), and it soon became a general archetype. The south tower of St. Stephen's church in Vienna was completed in 1433, and with its 137-meter height it was the tallest stone spire of its time. The Viennese tower had significantly improved upon the Freiburg one not only artistically, but structurally as well. This improvement did not happen in one

${ }^{215}$ ZYKAN 1967 (see in note 44), Fig. 12. 
single step. Two smaller Gothic towers in the onetime Kingdom of Hungary represent two important stages of this evolution: the one of the Franciscan monastery in Bratislava, and the one of the Franciscan (now Benedictine) monastery in Sopron.

For the Bratislava tower the dating of 1400 is widely accepted by the secondary literature. Through the on-site examination of the masonry of the St. John's chapel next to the Franciscan church evidence was obtained that it was built in only one campaign, and was completed in a short period of time. It can be dated accurately using a written source from 1361. During the on-site research several similarities were found between the chapel and the tower-some of them in detail -, so their building time could not be far from each other. Analysis of the motifs, forms of the tower also buttresses an earlier dating than 1400. Both the tower and the chapel share similarities in layout, forms, and stonemasons' marks to parts of the St. Stephan's church completed during the reign of Rudolf IV (1358-1365). The personal connection to Vienna seems to be a business partner of judge Jacob, who is regarded as a donator of the chapel. The similarities of the Bratislava chapel and tower to the contemporary parts of the St. Stephen's church hint that the workshop of Rudolf IV, the so called Herzogswerkstatt was active in Pressburg too.

There aren't any survived contemporary sources available about the construction of the Sopron tower. The construction date between 1380-1410 is accepted in the literature. This dating by Jenö Házi from 1961 is based on his assumption that Heinrich Gaissel was the donator. According to the later literature, the donator was his brother, Nikolaus Gaissel, who was judge of Sopron as early as 1361, and in 1366 he inherited a fortune. As the donation, so the layout, formation, and forms of the tower do not justify the late dating. The unusual layout of the tower - situated next to the nave, with a portal on its ground floor, shaping a new north-south axis to the church - is the same as the layout of the Viennese south tower, going back to Rudolf IV. A distinctive element of the Sopron spire is its stone gallery near the top. Similar galleries are shown on original glass paintings of the Viennese choir, dated to 1340-1350. The Viennese connections also manifest themselves in the person of the donator: the brother-in-law of Nicolaus Gaissel was judge in Vienna. Further parallels in style can be identified in the St. John's chapel and the Franciscan tower in Bratislava. Since the architectural parallels are originated in the middle of the 14th century, and the large heritage of the donator dates to 1366 , the second half of the 1360's seems to be the most plausible building time, and the builders could be the members of the St. Stephen's lodge, as in Bratislava.

Tim Juckes proved that during the long construction history of the St. Stephen's nave several innovations of the lodge were realised earlier outside of Vienna (occasionally in the Kingdom of Hungary) then on the St. Stephen's church itself. The situation seems to be similar during the several decade long construction of the south tower: the most important architectural components, which distinguish it from the paragon Freiburg tower can be found on smaller, older towers in Vienna and its neighbourhood. The literature connects the towers in question (Gaming, Maria Straßengel, Deutsch-Altenburg, Maria am Gestade) to the lodge of the St. Stephen's church. Both the Bratislava and the Sopron tower fit perfectly in their series. Both towers are closely tied to the Vienna lodge, and on both tower appear components which are not present in Freiburg, but are important features in the appearance of the Vienna tower. These components were realised in Bratislava and Sopron earlier than in Vienna. 